\title{
Spiny lobster development: where does successful metamorphosis to the puerulus occur?: a review
}

\author{
Bruce Frank Phillips • Paulette S. McWilliam
}

Received: 24 June 2008/Accepted: 31 October 2008/Published online: 21 November 2008

(C) The Author(s) 2008. This article is published with open access at Springerlink.com

\begin{abstract}
This review re-addresses the question: Where does metamorphosis to the puerulus mainly take place among the shallow-water palinurids? A decade ago we reviewed this ecological question in a paper that focused on phyllosomal development of the western rock lobster, Panulirus cygnus. The main region of occurrence of its metamorphosis was found to be in the slope region beyond the shelf break. Because the puerulus of $P$. cygnus is a non-feeding stage, it was hypothesised that metamorphosis will not occur until the final phyllosoma has reached some critical, and specific, level of stored energy reserves. For late larval development and successful metamorphosis of $P$. cygnus, the richest food resources seem to be located in the slope waters adjoining the shelf break off Western Australia. This, like most shelf break areas, is a region of higher zooplankton and micronekton biomass than is usually found further offshore, and is dominated (in winter-spring months) by the warm south-flowing Leeuwin Current. In this
\end{abstract}

B. F. Phillips ( $\square)$

Department of Environmental and Aquatic Sciences, Curtin University of Technology, G.P.O. Box U1987, Perth, WA 6085, Australia

e-mail: b.phillips@curtin.edu.au

P. S. McWilliam

18 Moroak Street, Hawker, ACT 2614, Australia new review, distribution and abundance data of final phyllosomas and pueruli are examined from, Рапиlirus argus, Panulirus cygnus, Panulirus japonicus, Panulirus ornatus and Jasus edwardsii, and where possible, related to features of the satellite imagery of the areas in which they occur. We hypothesise that metamorphosis will occur where the final stages have partaken of sufficient, appropriate nutrition to provide them with a reserve of bioenergetic resources, and this can occur where oceanographic fronts effect greater planktonic productivity and concentrations of food organisms. This may be near the shelf-break, or out to large distances offshore, because of large-scale oceanographic events such as the prevailing current system, its off-shoots, mesoscale eddy fronts, counter-currents, etc. However, we contend that, in terms of population recruitment, metamorphosis in most shallow-water palinurid species occurs mainly in the slope waters adjoining the shelf break of the region to which the species is endemic. Although some final phyllosomas may metamorphose much further offshore, it is unlikely that these pueruli will reach the shore, let alone settle and successfully moult to the juvenile stage. All of the data indicate that successful metamorphosis from the final-stage phyllosoma to the puerulus stage in all species occurs offshore but close to the continental shelf.

Keywords Location of metamorphosis . Nutrition · Ocean fronts · Phyllosoma . Puerulus $\cdot$ Spiny lobsters 


\section{Introduction}

The final-stage phyllosomal larva of spiny (or rock) lobsters (Decapoda, Palinuridae) metamorphoses into the puerulus (the postlarva). An outline of phyllosomal development and metamorphosis in these shallow-water palinurids is given in the Introduction in McWilliam and Phillips (2007), which is included in this two-part review.

As reported by Booth and Phillips (1994) there is evidence that most metamorphosis takes place mainly near the continental shelf break because that is where final stages are usually most abundant. The puerulus is a transitional, nektonic stage (well-adapted for strong, horizontal, directional swimming) (see also Jeffs and Holland 2000), which bridges the planktonic and benthic phases of the life cycle. It is a shortlived (ca. 3-4 weeks) non-feeding, stage (ca. 30-35 mm in total length) which swims across the continental shelf towards the shore. Because the puerulus is a non-feeding, postlarva, it does not aggregate at the surface at night. It is sparsely distributed in the plankton and has only been caught in small numbers by plankton sampling (Phillips et al. 1978). How it navigates shoreward has not yet been determined (see Jeffs et al. 2005). When the puerulus reaches shallow water near the shore, it settles. Its exoskeleton becomes pigmented and calcified just prior to its moult to the first benthic juvenile stage which resumes feeding.

It is a decade since we first reviewed the question of what induces metamorphosis to the puerulus, and where it mainly occurs (McWilliam and Phillips 1997). Our 1997 review focused on phyllosomal development of the western rock (spiny) lobster, $P$. cygnus, endemic to Western Australia, and extrapolation from results of laboratory rearing of other larval decapods as well as other species of spiny lobsters.

The stimulus for a re-examination of the question was an invitation by the editors of The Lobster Newsletter (http://www.odu.edu/ mbutler/newsletter/ index.html) for readers to make comments on the following topics:

Where does metamorphosis to the puerulus stage mainly take place among the shallowwater palinurids, and what factors - internal and/or external - are implicated in its progression?
Five articles responding to this invitation were published in the December 2005 issue of The Lobster Newsletter (Jeffs 2005; Yeung 2005; Dennis 2005; Booth and Chiswell 2005; Yoshimura 2005).

The second (physiological) question of the topic in The Lobster Newsletter (2005) has been examined as a review of the molecular mechanisms inducing metamorphosis to the puerulus by McWilliam and Phillips (2007).

In this paper we address the first (ecological) question. We concentrate on data on the shallowwater, palinurid species discussed in the Newsletter articles, viz. J. edwardsii, P. argus, P. cygnus, $P$. japonicus, and $P$. ornatus. The purpose of this review is to assemble and assess all relevant, available information on the location where metamorphosis may mainly occur, thereby increasing the background knowledge for future fisheries research into these commercially valuable species: also to provide a background literature search, including cases; such as $P$. argus, where there is a paucity of sampling data for final-stage phyllosomas. It is important to know where metamorphosis takes place because if we are to develop models of lobster fisheries we need to model larval behaviour, including what factor(s) induces metamorphosis, when it is established. Clearly this factor determines where metamorphosis occurs, and we need such observations to help 'tune' the model of larval behaviour.

\section{Terminology}

Before proceeding, it is necessary to define several terms, because of the ambiguities of meaning in their use in the general literature.

\section{Metamorphosis}

This occurs in spiny lobsters at the last larval moult when the final phyllosomal stage emerges as a puerulus which has a body plan resembling the adult and is vastly different from the phyllosomal morph; it also undergoes a change in behaviour, locomotion and metabolism from the larval stages. The term is used in this complete sense here. The puerulus is morphologically adapted as a strong swimmer. Whereas the long, thoracic appendages are used for (mainly vertical) swimming in the zoeal form of larva (i.e. the 
phyllosoma), these become shorter, uniramous, walking-type legs in the puerulus, which has relatively large pleopods, both rami similar in size and fringed with plumose setae, plus appendices internae on their endopods. These appendices, hooked to the opposite pleopod pair by cincinnuli, enhance forward swimming by synchronous sweeping movements. These morphological features are unique to the puerulus of spiny lobsters and non-functional in succeeding developmental stages, being gradually diminished through the juvenile instars as the pleopodal endopod is reduced and resorbed (see Abrunhosa and Kittaka 1997, Figs. 1, 3-8). Also, in all palinurids, metamorphosis occurs before settlement of the postlarva (see Gore 1985; Felder et al. 1985). This is true also of the postlarva of most known decapods that do not show abbreviated development (Felder et al. 1985). It is also true of the Scyllaridae (slipper lobsters) another family in the Achelata (formerly Palinura) whose postlarva is called a nisto.

\section{Shelf break}

This is where the continental shelf joins the continental slope. In most continents, including Australia, this in general occurs at the $200 \mathrm{~m}$ isobath, so the latter is generally regarded as the demarcation line for the edge of the continental or insular shelf, i.e. the 'shelf break', and this marker is used in the present paper. The width of the continental shelf varies geographically within and among continents. In the latitudinal distribution of P. cygnus off Western Australia it ranges from ca. 45 to $80 \mathrm{~km}$ but is mainly narrower in the regions of New Zealand and Japan inhabited by J. edwardsii and $P$. japonicus, respectively. In these regions, there is a more sudden 'drop-off', rather than a slope, just beyond the shelf break, as there is off the Great Barrier Reef (GBR) of north eastern Australia where the phyllosomas and pueruli of P. ornatus occur (Dennis et al. 2001). In the Florida Keys, where early developmental stages of $P$. argus have been sampled, the shelf ranges from ca. 3 to $30 \mathrm{~km}$ in width (Yeung et al. 2001).

Shore, onshore, offshore

In strict parlance, the 'shore' or 'shoreline' (also 'coastline') is where the land meets the sea. 'Onshore' and 'offshore' generally mean, respectively, 'towards the shore' and 'away from the shore' and are usually applied to wind direction, However, in this paper we use such terms regionally-'onshore' meaning in the region from shoreline to shelf break; that is, 'over the shelf' or in shelf waters (i.e. strictly coastal waters), and 'offshore' meaning 'in waters beyond the shelf break', (i.e. oceanic waters). These definitions use the shelf break as the line of demarcation between shelf and oceanic sampling stations. Yeung (2005) argued for a line at $100 \mathrm{~m}$ in the central West Atlantic, but whatever is used, it should be clearly defined by each researcher to avoid confusion.

In this paper we have not attempted to guess what authors may have meant by 'coast', etc. Nor have we tried to recalculate distances offshore from particular locations. However, where we are uncertain, or would suggest such measures could be modified to produce more accurate information, we have marked such instances by [sic].

\section{Sources of data}

All conclusions about distributions of phyllosomas and pueruli in the wild are based on the results of sampling and this sampling depends on the objectives of the particular study. However, there are many gaps in information because, usually, the sampling has not been designed to answer the above specific questionwhich requires sampling from the shelf break to well offshore in order to assess the locations, relative to the shelf break, where final-stage phyllosomas of each species are generally most abundant. A severe biasing problem is introduced if samples are taken only on the shelf, and not beyond the shelf break. In addition, many cruises have not included oceanic sampling stations that were a long way from the shelf.

Table 1 summarises the relevant data that are available on the phyllosomas and pueruli of the species discussed in this paper that have been caught in the plankton.

\section{Distribution and abundance of phyllosomas and pueruli}

\section{Jasus edwardsii}

\section{Phyllosomas}

A number of studies to examine the larval recruitment of $J$. edwardsii in New Zealand were undertaken 


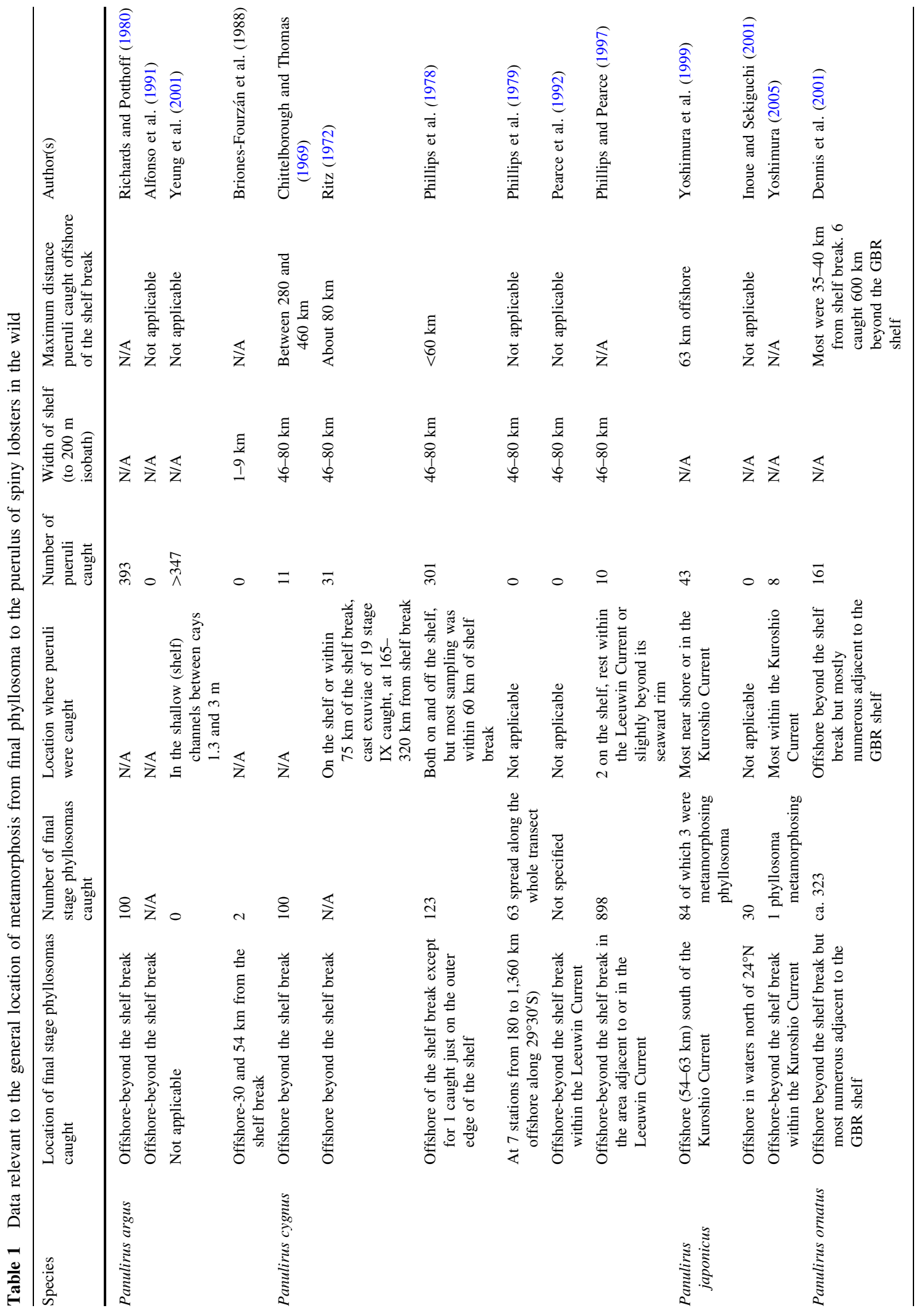




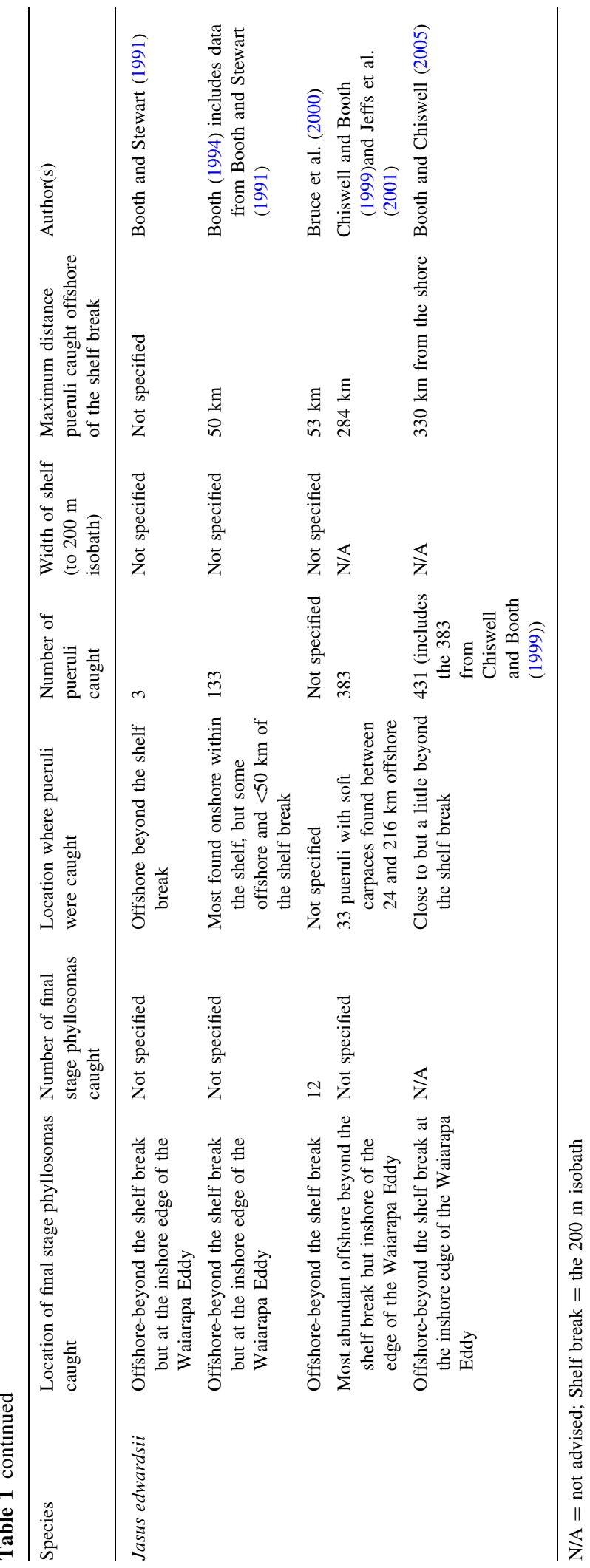


between the 1970s and 1990s. The results of these investigations were summarised by Booth (1994) who reported that 'advanced' phyllosomas (stages $\mathrm{V}$ to XI, the final stage in this species) were found almost exclusively seaward of the continental slope and widely distributed from about $20 \mathrm{~km}$ seaward of the shelf edge out to $900 \mathrm{~km}$ from the mainland. The highest abundance of advanced phyllosomas was off the east coast of the North Island, south of East Cape, and far fewer larvae of any stage were taken off the South Island. Booth (1994) found 2,184 advanced stage phyllosomas near the Louisville Ridge, 1,300 km off the North Island of New Zealand.

Additional sampling on five cruises between June 1988 and April 2001 (Chiswell and Booth 2005) showed that, on four of the five cruises, latestage (IX, X, and XI) phyllosomas were found further inshore $(49 \mathrm{~km})$ than mid-stage phyllosomas. Mid-stage (V to VIII) larvae appeared to be contained within a large semi-permanent eddy found offshore, known as the Wairarapa Eddy, whereas the late stages have been found along the inshore rim of the eddy (Chiswell and Booth 1999, Fig. 1).

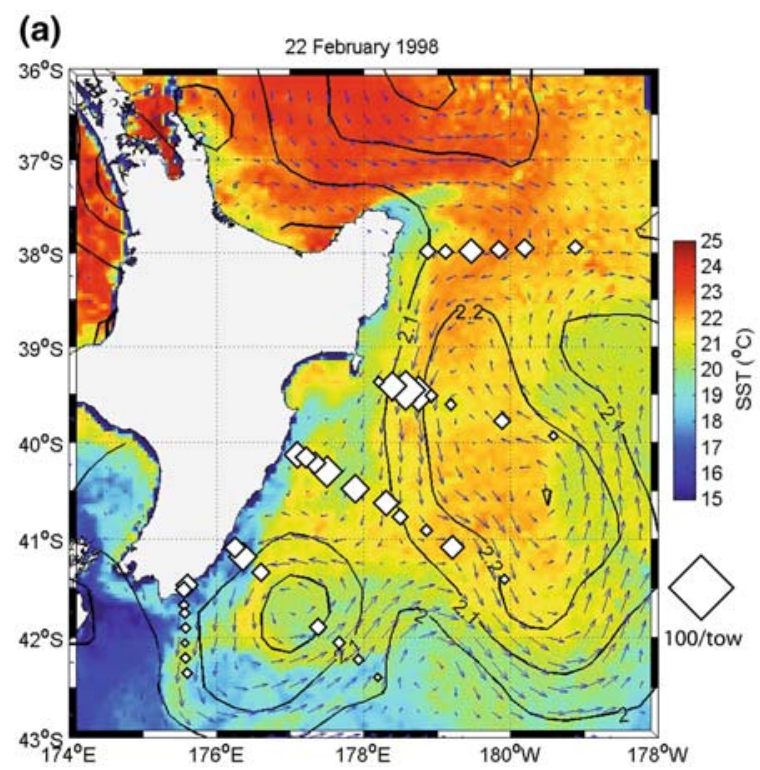

Fig. 1 Distribution of Jasus edwardsii a pueruli, b newly metamorphosed pueruli caught off the east coast of New Zealand in February 1998 superimposed on dynamic height

\section{Pueruli}

Booth (1994) reported that most pueruli (>400) of J. edwardsii have been caught either over the shelf or just seaward of the shelf break.

Chiswell and Booth (1999) conducted a sampling program off the east coast of New Zealand in February 1998. They caught 383 pueruli of which 33 had softcarapaces, so it was assumed that they had recently moulted from the last phyllosomal instar (see Fig. 1). This 1998 cruise, which occurred during part of the 1997-1998 El Nino year, was also regarded as anomalous in that both newly metamorphosed and nektonic pueruli were caught well offshore. Jeffs et al. (2001) discussed the 33 new pueruli, collected by Chiswell and Booth in 1998. These new pueruli were captured between 24 and $216 \mathrm{~km}$ offshore (mean of $94 \mathrm{~km}$ ), indicating that most were caught somewhere in between these distances, but still well beyond the shelf break (Jeffs et al. 2001, Fig. 1d). The eastern shelf of the North Island is very narrow-typically ca. $30 \mathrm{~km}$ wide, so most of the pueruli caught would have been off the shelf.

Chiswell and Booth (2005) carried out an extensive review of all of the data from five cruises between June

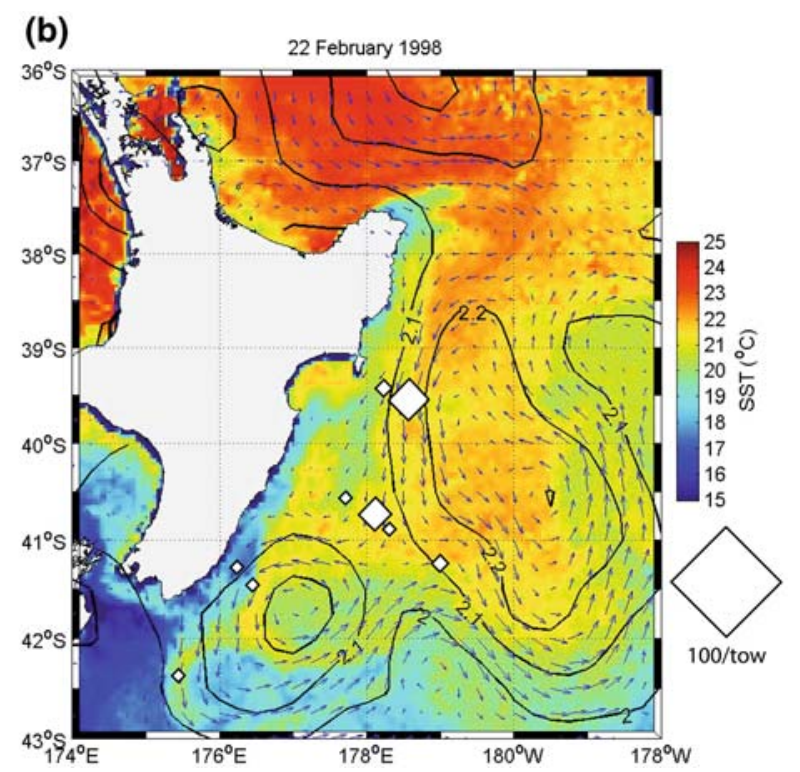

calculated from AVISO satellite data for the same time period. The data are from Chiswell and Booth $(1999,2005)$ and S.M. Chiswell (pers. com.) NIWA, New Zealand 
1988 and April 2001, including the cruise in February 1998. In the one cruise in which they could test latestage phyllosomas against newly metamorphosed pueruli, they found no statistical difference in the distributions. The pueruli sampled had a mean distance offshore of $71 \mathrm{~km}$, and the 33 new pueruli were caught over the same distributional range (mean distance offshore, $93 \mathrm{~km}$ ) as the late stage phyllosomas (mean distance offshore $104 \mathrm{~km}$ ). They concluded that metamorphosis to the puerulus takes place throughout the spatial range of the late-stage phyllosomas, which is clearly offshore of the shelf break.

\section{Panulirus argus}

\section{Phyllosomas}

Through the 1960s and 1970s there have been many studies of the numbers of phyllosomas and pueruli of this species caught in plankton sampling (both deliberate and incidental) in the Florida Keys and adjoining regions (see review by Lyons (1981), and citations in Yeung and McGowan (1991)). Although many were concerned with establishing the mainly 'downstream' Caribbean larval recruitment to Florida stocks, most of these studies up to the 1990s have suffered from two factors that would preclude the assessment of where metamorphosis of this species generally occurs:

- Very few sampling stations were located beyond the shelf off the Florida Keys.

- Until recently it was difficult to separate the late stage larvae, as well as early and middle stages, of the three congeneric species occurring in the region, viz $P$. argus, Panulirus guttatus and Panulirus laevicauda.

This means that all earlier phyllosomal counts could have been biased as they were lumped as "Panulirus spp.", or attributed to $P$. argus, because the latter was regarded as likely to be the most abundant species (Sims and Ingle 1966). Similarly Richards and Potthoff (1980) reported on an examination of 13,770 specimens of phyllosomas and pueruli held by the Florida Department of Natural Resources, but were unsure of their identification. This uncertainty also includes the data of Yeung and McGowan (1991) whose sampling transects were mostly on the shelf and extended "from the edge of the reef tract (2-4 km offshore) to the approximate edge of the shelf (30 km offshore), or less". Therefore their 'shore' meant 'shoreline', and their Table 1 indicates only nine stations were at $200 \mathrm{~m}$ or more depth (262 $\mathrm{m}$ at the furthest offshore station). They did not catch any final-stage (XI) phyllosomas, and only one subfinal stage (X).

Studies of distribution of phyllosomas of P. argus in other regions of the Caribbean, e.g. Cuba (Baisre 1976; Alfonso et al. 1991), have indicated that, as with other palinurid species discussed here, mid- and late-stage larvae were almost exclusively found off the continental or island shelves, ergo metamorphosis of this species primarily occurs beyond the shelf break, as had been surmised by earlier researchers (see review by Lyons 1981). However, very few, if any, final-stage larvae of this species have been caught in any of these regions.

Manzanilla-Dominguez and Gasca (2004, Table II) working in the Gulf of Mexico and Yucatan waters, reported the catch of one subfinal stage (X) specimen of $P$. argus in the southern Gulf of Mexico and stated that "the largest specimens (stages VIII$\mathrm{X}$ ) of $P$. argus [collected] were recorded on the shelf and shelf border areas of the Campeche Bank". In addition, 10 late -stage phyllosomas are shown at four mid-shelf sampling sites.

Since the distribution of the final stages is vital in answering the question, identification and separation of the late-stages of P. laevicauda (see Baisre and Ruiz de Quevedo 1982), from those of P. guttatus (see Baisre and Alfonso 1994), and the separation of the final stage of the two former species from that of $P$. argus, is now facilitated because the latter species has been cultured from egg to juvenile and its phyllosomal stages described (Goldstein et al. 2006, 2008).

\section{Pueruli}

All of the data on the distribution of the pueruli of $P$. argus in the Florida Keys are based on collections made too far inshore, and without appropriate offshore sampling, to provide information on the location of metamorphosis from the final phyllosomal stage (e.g. Yeung 2005; Yeung et al. 2001).

However, the study of Briones-Fourzan et al. (2008) off the Yucatan Peninsula in Mexico clearly showed that the pueruli of $P$. argus are in the oceanic waters beyond the shelf and that the physical forces of waves and swell, including those caused by the action of hurricanes, are part of the forces transporting them into 
Fig. 2 The approximate extent of larval sampling for Panulirus cygnus that has been undertaken off Western Australia by Chittelborough and Thomas (1969) (dashed black line); Ritz (1972) (black rectangle): Phillips et al. (1979) (dotted black line), and Phillips and Pearce (1997) light purple rectangle

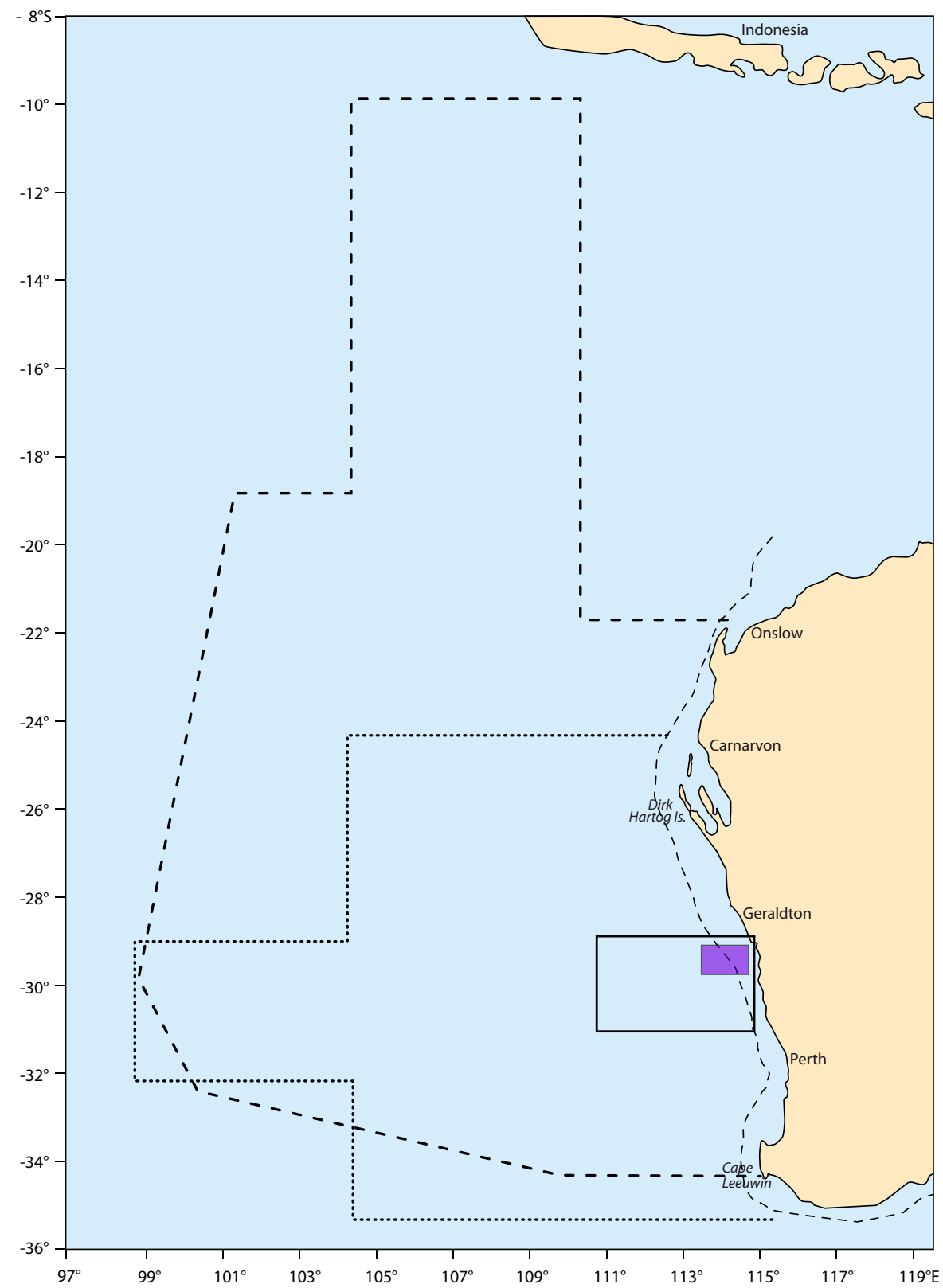

the coastal back-reef, coastal lagoons and shallow bays. From this it may be inferred that metamorphosis of this species occurs offshore.

\section{Panulirus cygnus}

\section{Phyllosomas}

Panulirus cygnus in Western Australia is the species in which the oceanic phase of the life cycle has been studied most thoroughly. Extensive oceanic sampling of $P$. cygnus in the 1960 s through to the 1990 s was aimed initially at an understanding of the distribution and ecology of the phyllosomas and then focussed on understanding the ecology of the puerulus stage in the oceanic recruitment of this species. Sampling was conducted over a vast area from $9^{\circ} 00^{\prime} \mathrm{S}$ to $34^{\circ} 36^{\prime} \mathrm{S}$ and from the west coast of Australia out to $100^{\circ} 39^{\prime} \mathrm{E}$ (see Fig. 2). The biological program was supported by oceanographic studies of the area off Western 
Australia which have continued right to the present day (see Waite et al. 2007a).

Spatial and temporal field studies by Chittelborough and Thomas (1969), Ritz (1972), Phillips et al. (1978, 1979) Phillips and Pearce (1997) and the review by Phillips (1981), showed that the larvae of $P$. cygnus were widespread in the eastern Indian Ocean. Using the nine stages described by Braine et al. (1979) the phyllosoma were assigned to stages I, II and III as early stages, IV and V as mid-stages and VI, VII, VIII and IX as late-stage phyllosomas, stage IX in this species being the final stage which metamorphoses to the puerulus.

In a study to examine the distribution of phyllosoma larvae on and off the shelf in August, September and October 1974, only 9 out of 1,169 late-stages (stages VI to IX) phyllosomas were caught on the shelf and these were caught towards the outer edge of the shelf (Phillips et al. 1978). Mid- and late-stage larvae in the Phillips et al. (1979) study were found in greatest numbers offshore but near the edge of the continental shelf and were normally absent in shelf waters or, when present, in very small numbers and confined to the outer edge of the shelf.

A wide spatial survey in 1976 and 1977 caught 19,744 phyllosomas and, during midwinter, there were no stations beyond the continental shelf between $24^{\circ} 30^{\prime} \mathrm{S}$, and $35^{\circ} 00^{\prime} \mathrm{S}$, out to $99^{\circ} 00^{\prime} \mathrm{E}$ at which at least some phyllosoma were caught (Phillips et al. 1979, Fig. 4). In May 1976 the greatest concentration of late-stage (VI to IX) phyllosomas along $29^{\circ} 30^{\prime} \mathrm{S}$ was between $103^{\circ} 00^{\prime} \mathrm{E}$ and $109^{\circ} 00^{\prime} \mathrm{E}(500-1,080 \mathrm{~km})$ offshore (Phillips 1981); and along $29^{\circ} 30^{\prime} \mathrm{S}$ in September 1976, final-stage phyllosomas, were present at all stations from $99^{\circ} 70^{\prime} \mathrm{E}$ (approximately $1,500 \mathrm{~km}$ offshore and 1,360 km from the shelf), the maximum distance offshore sampled during this cruise, to $111^{\circ} 80^{\prime} \mathrm{E}$ (Phillips et al. 1979, Fig. 5). No pueruli were caught at any of these stations.

The study by Pearce et al. (1992) in August/ September 1987, consisting of three transects across the continental shelf at $28^{\circ} \mathrm{S}, 29^{\circ} 07^{\prime} \mathrm{S}$ and $29^{\circ} 45^{\prime} \mathrm{S}$, found a strong dependence on the water masses associated with the Leeuwin Current. This current was first named by Cresswell and Golding (1980). Phyllosomas were found exclusively off the shelf, i.e. in the outer region of the Current, and all were stages VI to IX. The final-stage (IX) larvae were all concentrated at the stations along the shelf break just inshore of the Leeuwin Current.

In September, 1991 a study near the edge of the shelf by Phillips and Pearce (1997), caught 3,199 phyllosomas. Sampling was conducted at the surface and sub-surface for distributions of the phyllosomas (and pueruli) in a period when the Leeuwin Current overran the outer edge of the shelf in the sampling region. The data on final-stage phyllosomas and zooplankton biomass were presented in the review by McWilliam and Phillips (1997). They are shown here in Fig. 3. None of the final-stage phyllosomas was caught on the shelf. Most final-stage phyllosomas (Fig. 3b) were caught offshore, within the Leeuwin Current but nearer its seaward margin which, because of the current overrun, was close to the shelf break. This region was also where biomass values were highest (Fig. 3a).

\section{Pueruli}

Most of the $>500$ pueruli of $P$. cygnus caught in the plankton have been taken in shelf waters or slope waters near the shelf-break (Phillips et al. 1978). However, small numbers have been caught further offshore. Chittelborough and Thomas (1969) recorded one specimen $130-259 \mathrm{~km}$ offshore, two at somewhere between 259 and $389 \mathrm{~km}$ and one at somewhere between 359 and $519 \mathrm{~km}$. The sampling methods used at that time did not permit greater accuracy as to the distance offshore.

Ritz (1972) also caught 19 cast exuviae of finalstage phyllosomas at more than $161 \mathrm{~km}$ (ranging from 215 to $400 \mathrm{~km}$ ) from the shore [sic] of Western Australia (see Ritz 1972, Fig. 8). It is possible that these exuviae may have been transported some of the distance offshore by the surface currents in this area which are known to transport the early stage I phyllosomas offshore (Phillips 1981) or perhaps by a westward propagating warn-core eddy (Waite et al. 2007a). However, Ritz also pointed out that $80 \%$ of the pueruli were caught within $60 \mathrm{~km}$ of the coast [sic].

In the August/September 1987 study by Pearce et al. (1992) no pueruli were caught in the waters over the shelf and it was suggested that metamorphosis to the puerulus occurs beyond the shelf (and perhaps in the Leeuwin Current) and that movement towards the shore by the pueruli is subsurface (Pearce et al. 1992). 

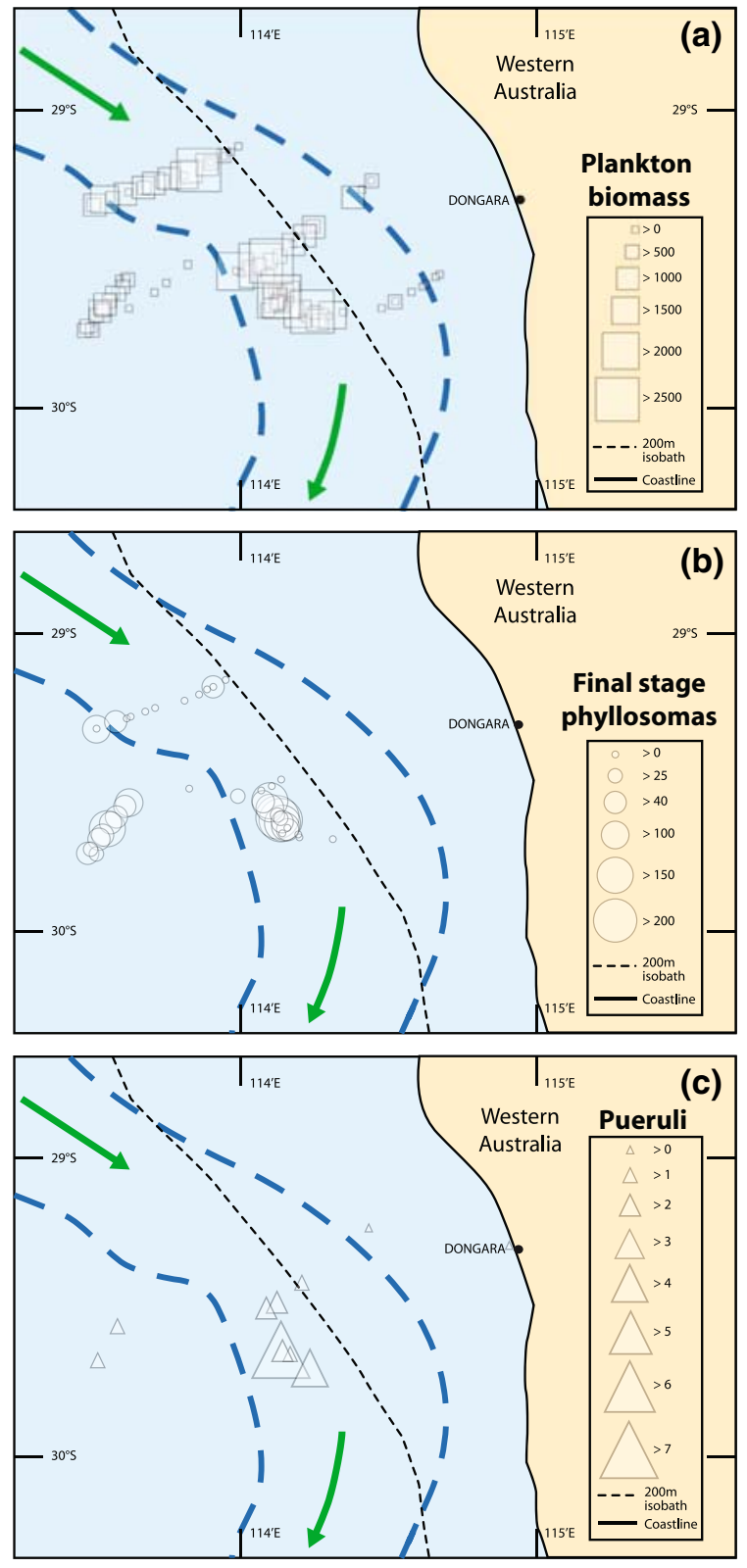

Fig. 3 a Plankton biomass, measured as wet weight in cubic metre of water filtered, from all samples. b Numbers of finalstage (IX) phyllosomas of Panulirus cygnus per $10,000 \mathrm{~m}^{3}$ of water filtered, and c Numbers of pueruli of Panulirus cygnus $10,000 \mathrm{~m}^{3}$ of water filtered, collected in these samples from the shelf-break region off Western Australia, September 1991. All data are from Phillips and Pearce (1997). Dashed lines indicate approximate boundaries of the Leeuwin Current as determined from satellite images; arrows indicate direction of current flow. The $200 \mathrm{~m}$ isobath is a black dashed line

In the September 1991 study by Phillips and Pearce (1997), most pueruli were found offshore near the edge of the shelf break, but they were found in greatest numbers close to and offshore of the shelf (Fig. 3c) in the same location where the final-stage phyllosomas were most abundant and biomass values highest.

\section{Panulirus japonicus}

\section{Phyllosomas}

A number of studies of the distribution of phyllosomas of $P$. japonicus have been conducted, including those of Yoshimura et al. (1999), Inoue and Sekiguchi (2001) and Yoshimura et al. (2002).

Inoue and Sekiguchi (2001) sampled beyond the shelf, but adjacent to it, in waters south of the Kuroshio Subgyre which is south of Kyushu, Japan. They clearly showed that the phyllosomas of P. japonicus were beyond the shelf and most of the 30 finalstage larvae caught were in the northern part of the waters east of the Ryuku Archipelago (Inoue and Sekiguchi 2001, Fig. 3).

The numbers of phyllosomas (especially the final stage) caught during these and earlier cruises were low and as reported by Yoshimura et al. (2002) "Very little is known about the scale and processes of transport of $P$. japonicus larvae. The problem lies in the ambiguity of species identification of larvae and the small number of samples collected from the plankton."

This identification problem should now be largely overcome because of recent molecular species identification and descriptions of mid- and late-stage phyllosomas of Panulirus species occurring in Japanese waters by Chow et al. (2006a, b) and Shirai et al. (2006).

Further biological/oceanographic studies might reveal that the interannual and decadal changes in the path of the Kuroshio Current along the shelf break of southern Japan (sometimes straight, sometimes with a small meander and sometimes with a large meander offshore (Tomczak and Godfrey 2005)) play an important role in the distribution and abundance of final-stage phyllosomas and puerulus settlement in this species.

\section{Pueruli}

The paper by Yoshimura et al. (1999) contains the most relevant data on the pueruli of this species. 
Between 1992 and 1995, on four research cruises, 43 pueruli of $P$. japonicus were caught. In 1992, 35 pueruli were captured in three hauls from an area off the edge of the shelf off south-western Japan. A further two pueruli were taken slightly further off shore in or south of the estimated position of the Kuroshio Current. In 1993 two pueruli were caught in six hauls in the same general location; and a final stage phyllosoma that was moulting to the puerulus stage was caught in the Kuroshio Current. None was caught north of the Current. These data are combined and are shown in Fig. 4.

Yoshimura et al. (1999) suggested that the finalstage phyllosomas of $P$. japonicus metamorphose to pueruli in the Kuroshio Current and the pueruli then swim across the Kuroshio Current to coastal areas to settle. But it is of interest that Yoshimura (2005) reported that "when the Kuroshio is more than 100 miles [about $160 \mathrm{~km}$ ] from the shore virtually no settlement of pueruli occurs." (a)

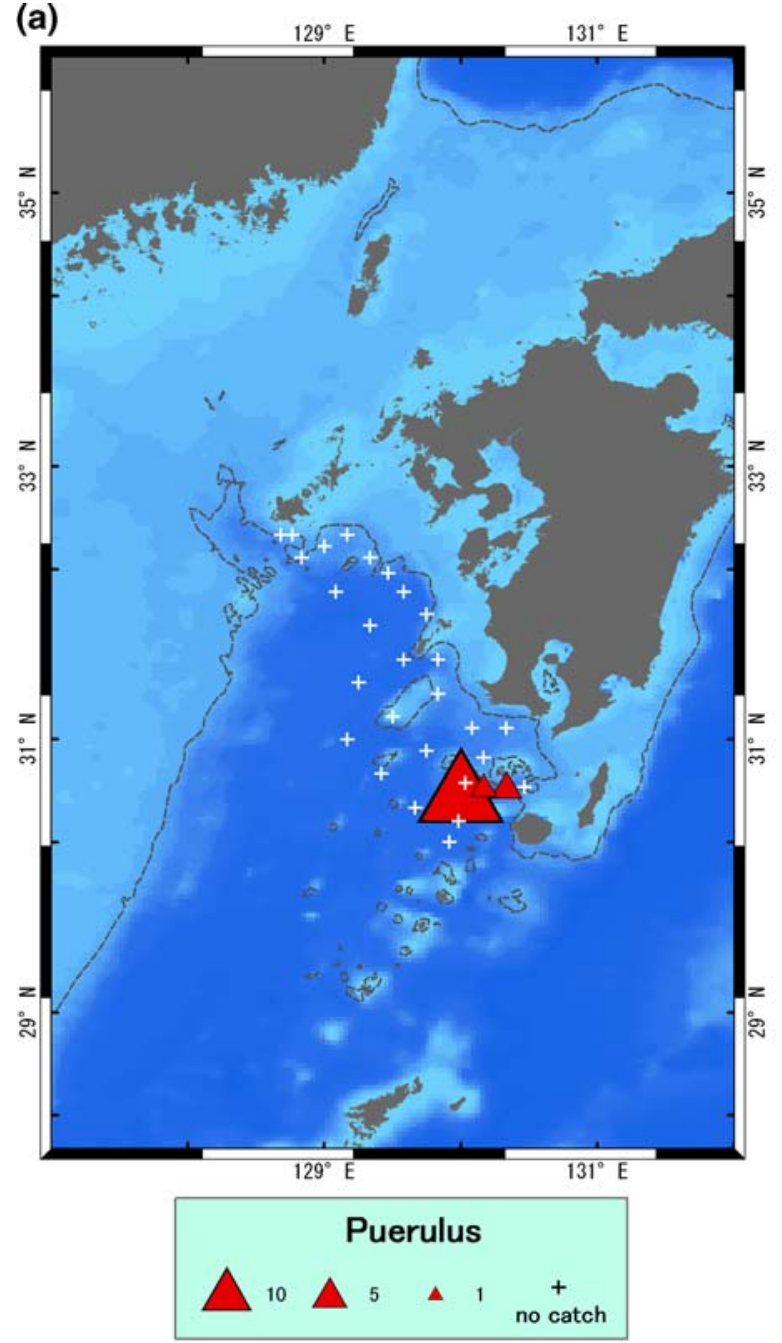

Fig. 4 a Distribution of Panulirus japonicus pueruli collected off southern Japan in 1992. b Distribution of Panulirus japonicus pueruli and phyllosomas collected off southern Japan in 1993. The pink shaded area indicates the area of the (b)

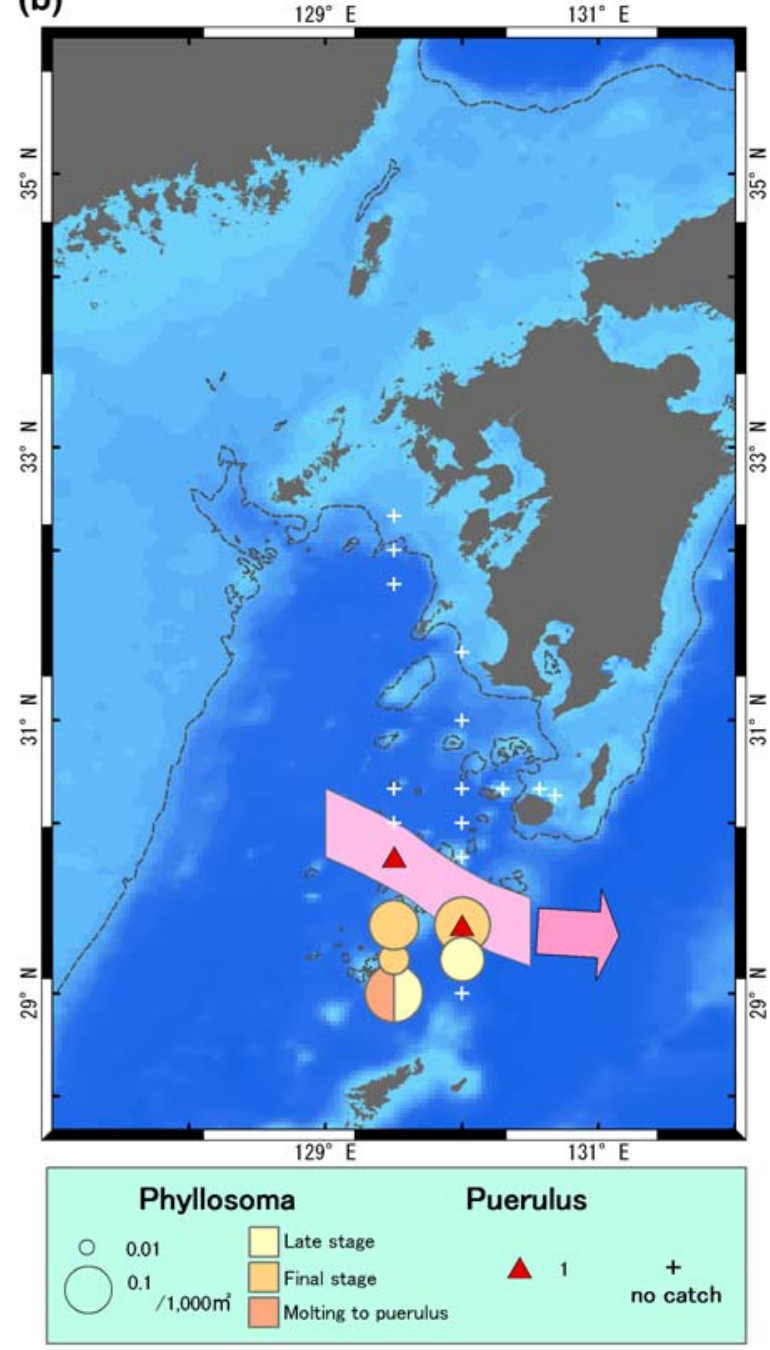

Kuroshio Current axis estimated from the temperature distribution at a depth of $200 \mathrm{~m}$. All data are from Yoshimura et al. (1999) who also kindly supplied the figure 


\section{Panulirus ornatus}

\section{Phyllosomas}

The only study of the distribution of the phyllosomas of P. ornatus is by Dennis et al. (2001) for the Coral Sea in May 1997. They caught 4,270 phyllosomas and 161 pueruli. Sampling was not conducted on the shelf and in most cases was restricted to about $30 \mathrm{~km}$ beyond the edge of the GBR. The phyllosomas were generally restricted to the North West Coral Sea. Final-stage phyllosomas were most abundant at a station about $300 \mathrm{~km}$ directly east of the Queensland coast and also at locations adjacent to the GBR shelf break, mainly north of Princess Charlotte Bay (see Dennis et al. 2001, Fig. 5c).
In the $P$. ornatus larval modelling investigation by Pitcher et al. (2005), they stated: "[it was] assumed that once phyllosomas are at least 120 days old, they can metamorphose to the puerulus if they find themselves in water $<100 \mathrm{~m}$ deep." In addition, they assumed that. "The continental shelf is extremely narrow throughout the eastern Papua New Guinea region, so a model larva of sufficient age that encounters the $100 \mathrm{~m}$ isobath (triggering metamorphosis) [sic]also encounters the $20 \mathrm{~m}$ isobath, triggering settlement [of the puerulus]." Both of these assumptions were introduced into the modelling process to allow the model to function, but they have no basis in fact, since the 'trigger' for metamorphosis in palinurid phyllosomas of any species has not yet been determined (see McWilliam and Phillips 2007);
Fig. 5 Distribution of the final phyllosomas (circles) and the pueruli (triangles) of Panulirus ornatus collected in the north-west Coral Sea off North East Australia in May 1997 by Dennis et al. (2001). The heavy black line skirting Queensland (GBR) and New Guinea coasts and Coral Sea reefs is the $200 \mathrm{~m}$ isobath. The arrows indicate location 4 where final stages were most numerous (i.e. $48 \%$ of all final stages were caught here- $300 \mathrm{~km}$ from the GBR shelf break) and the other = Location 5, about $600 \mathrm{~km}$ from the GBR shelf break, where 6 pueruli were caught. The satellite image taken on 12 May 1997 used in Fig. 5 was kindly provided by the CSIRO Division of Marine and Atmospheric Research
SST: 12-May-1997. SVP drifters (magenta): 07 May - 16 May Sealevel contours $(0.1 \mathrm{~m})$ and geostrophic velocity: 12-May-1997.

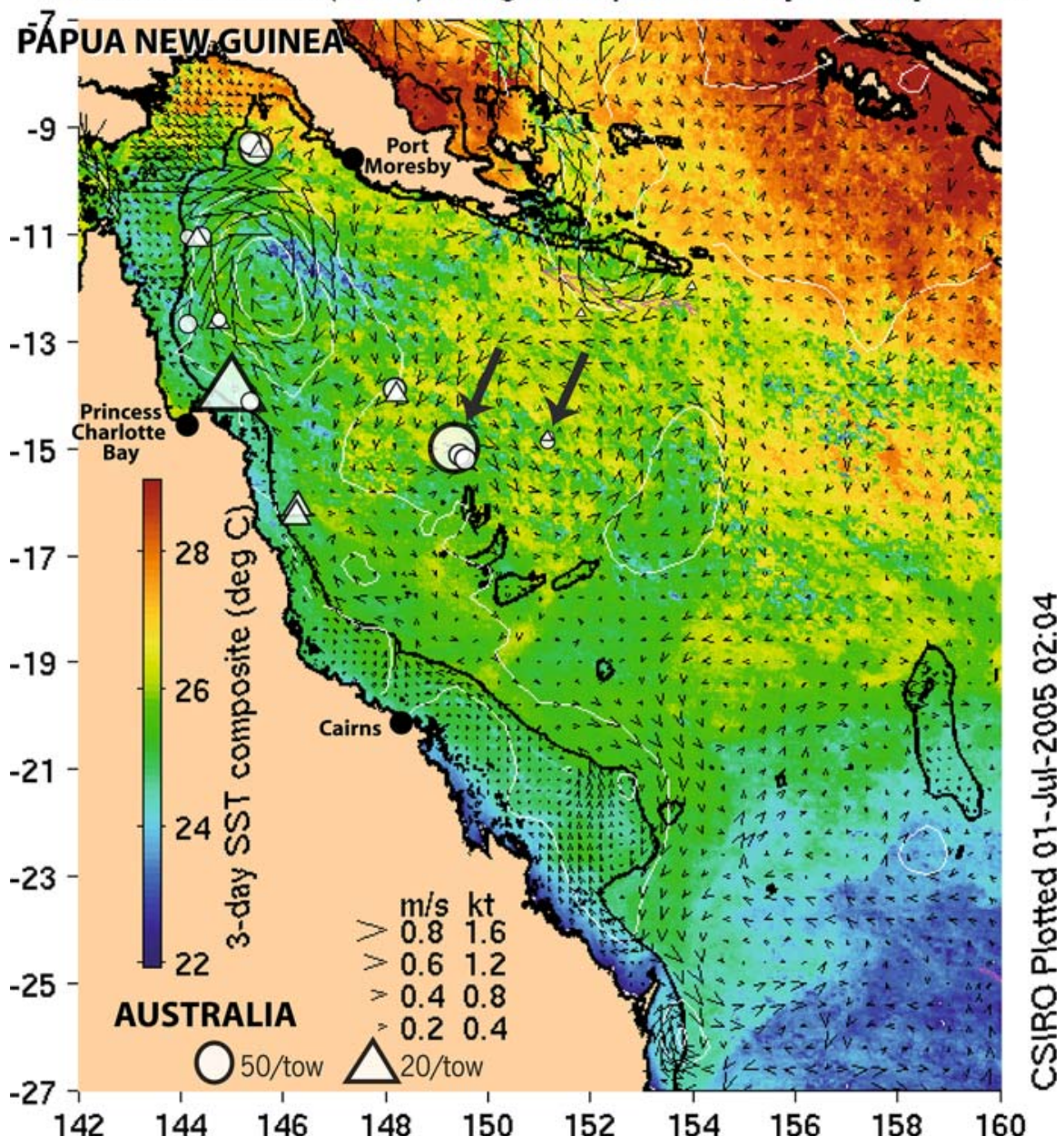


nor is the preferred substratum for settlement of pueruli of $P$. ornatus known. Therefore, their modelling study is invalid.

\section{Pueruli}

The only study of the distribution of the puerulus of P. ornatus is that reported by Dennis et al. (2001) for the Coral Sea in May 1997. Pueruli were most abundant at two locations (14 and 15) both near the GBR shelf break and south of Princess Charlotte Bay. About 45 of the total of 161 pueruli were caught at locations very close to the shelf break northeast of Cairns, but 6 pueruli were caught about $600 \mathrm{~km}$ east of the GBR. These data are shown here in Fig. 5.

\section{Integration of data for phyllosomas, pueruli and ocean circulation}

In this review we examine five regions:

- The South Pacific Ocean off the North Island of New Zealand

- The waters off the Florida Keys, USA and the Caribbean Sea

- The southeastern Indian Ocean off Western Australia

- The northwest Pacific Ocean off Kyushu, Japan.

- The Coral Sea between Papua New Guinea and Queensland, Australia

The general oceanography of all of these regions is now relatively well understood compared with our knowledge in the 1960s and 1970s, the times when most of the larval sampling was undertaken. This is largely because of the significant development of technology which includes satellite images, recording current metres, etc. and the use of computers to model these data. Unfortunately satellite images are not available for most of the periods of the sampling discussed above because the satellites had not then been launched. However, images showing relevant features of the circulation pertaining to each region are now available for all regions. The images used in this paper are from a variety of sources, each of which is acknowledged on the illustration.

The nature and extent of the circulation, including eddies and fronts shown in the images, and their relationships to the data on the location of final-stage phyllosomas and pueruli will be discussed in relation to the points raised in the Lobster Newsletter (2005).

\section{Jasus edwardsii}

The most conspicuous water circulation off the east coast of New Zealand is within the East Cape Current system. The area is marked by recirculation and eddying off the North Island. A major feature of the area is the large semi-permanent Wairarapa Eddy, which is believed to play a part in keeping phyllosomas close enough to the coast to allow successful recruitment (Chiswell and Booth 2005).

Booth and Chiswell (2005) and Jeffs (2005), dealing with $J$. edwardsii phyllosomas and pueruli off the southeast coast of the North Island of New Zealand (Chiswell and Booth 1999; Jeffs et al. 2001), stated that most pueruli caught by plankton sampling have been caught close to shore around the $1,000 \mathrm{~m}$ depth contour, i.e. out to a little beyond the shelf break, which is within $50-100 \mathrm{~km}$ of the coast (=shoreline), and that metamorphosis takes place near the shelf break. However, some pueruli were taken up to $330 \mathrm{~km}$ offshore. Later in the article, they added the comment that most metamorphosis in this species occurs inshore of the Wairarapa Eddy (see Jeffs et al. 2001, Fig. 1).

Jeffs (2005) stated that the only 'hard' evidence for the location of metamorphosis is the presence of newly moulted (i.e. soft-shelled) pueruli in samples. Jeffs et al. (2001), had further discussed the series of data on the J. edwardsii pueruli collected by Chiswell and Booth (1999) over a wide stretch of offshore waters, (between 24 and $216 \mathrm{~km}$ beyond the shelf break, mean of $94 \mathrm{~km}$ ). A statistical analysis comparing the characteristics of the water masses in which the newly moulted pueruli were caught and those in which they were not caught, was non significant (Jeffs et al. 2001). However, Jeffs (2005) reiterated that in $J$. edwardsii, metamorphosis of this species was associated with the inshore margins of the Wairarapa Eddy and its offshoots, as he had previously suggested (Jeffs et al. 2001).

The largest catch of newly moulted pueruli in the 1998 cruise, re-examined by Jeffs et al. (2001), was 12 out of 33 pueruli, taken at the locations shown here in Fig. 1b. This station was $72 \mathrm{~km}$ offshore. If we examine a representation of the circulation of the region at this time (Fig. 1), we see that this location is 
a jet of the East Cape Current located in the shoreward perimeter of the Wairarapa Eddy. New pueruli appeared to be generally distributed around the inshore margins of the Wairarapa Eddy, and absent from areas offshore and towards the centre of the eddy (Jeffs et al. 2001). For clarity, this is not the same representation of the circulation as presented by Jeffs et al. (2001, Fig. 1) which was based on the dynamic height from shipborne observations. This figure is based on dynamic height calculated from AVISO satellite data for the same time period.

\section{Panulirus argus}

Panulirus argus has such a wide distribution in the central western Atlantic that it is impossible to summarise the oceanic environment in which it occurs. However, the ocean circulation off the Florida Keys is marked by the warm Florida Current which passes close to the reef tract, and coastal eddies and counters currents (Yeung et al. 2001). Larval transport of $P$. argus may be driven by ocean currents, eddies and wind-driven currents, but the exact mechanisms are uncertain (Yeung and Lee 2002).

The article by Yeung (2005) addressed the topic with respect to P. argus stocks in the Florida Keys. She reported that metamorphosis is believed to occur "offshore", but was thwarted in answering the question about the specific location because the earlier studies, as well as the study by Yeung and McGowan (1991) only sampled onshore, to approximately the edge of the shelf, which is approximately $30 \mathrm{~km}$ from the edge of the reef tract, and they did not catch any final-stage larvae (XI). Yeung (2005) therefore focussed on discussing larval transport pathways across the coastal eddies in a circulation model of the Florida Keys and offshoots of the Florida Current and the Loop Current variations in the Gulf of Mexico (Lee et al. 1994).

\section{Panulirus cygnus}

A dominant feature of the ocean circulation off Western Australia is the Leeuwin Current, an anomalous poleward-flowing eastern boundary current that carries warm, low-salinity water southward along the shelf break of Western Australia (Waite et al. 2007a). This Current is stronger in the austral winter months, and its eddies are more frequent at this time of year, than in summer months, when its flow is weaker due to prevailing southerly winds.

McWilliam and Phillips (1997) found that the main region of occurrence of metamorphosis in $P$. cygnus in Western Australia could be inferred from the distribution and abundance of final phyllosomas, together with the location of the relative numbers of pueruli. Based on all the data available it was usually found to be in the slope region, offshore of the shelf break. It is important to realise that the seaward current border also represents a "front" and therefore also probably a more productive part of the offshore region.

In Western Australia satellite images and buoy tracks have now provided a completely different perspective to the knowledge of what may be happening with the Leeuwin Current (which was not even named until 1980) and the other parts of the circulation of the south-eastern Indian Ocean, to what was understood during the time period when most of the sampling was undertaken. Figure 6 shows the latest simplified schema of the surface currents off Western Australia (adapted from Waite et al. 2007a, Fig. 1).

It is clear from Fig. 6 that the Leeuwin Current can influence the ocean circulation over a wide area, and create a large "eddy field". This includes the production of mesoscale eddies, both anticyclonic warm-core (WC) and cyclonic cold-core (CC) eddies (Waite et al. 2007b). Both types of LC eddies propagate westward, the WC eddies have a poleward bias and $\mathrm{CC}$ eddies an equator-ward bias. A series of sea surface temperature fronts can be expected to occur over a wide area. Also each of these could potentially create localised conditions of higher plankton biomass such as the area identified by McWilliam and Phillips (1997) in the slope region offshore of the shelf break. Under such conditions "competent" final-stage phyllosomas might metamorphose into pueruli. The data from the widespread survey conducted by Phillips et al. (1979, Fig. 4) are shown in Fig. 7. All of the phyllosoma data on this survey could have been influenced by the Leeuwin Current, or its eddies if these conditions had prevailed.

Recent extensive studies of both types of LC eddies, including a counter-rotating pair of larger ones, have shown that primary productivity is much higher in WC eddies, as is the abundance and 


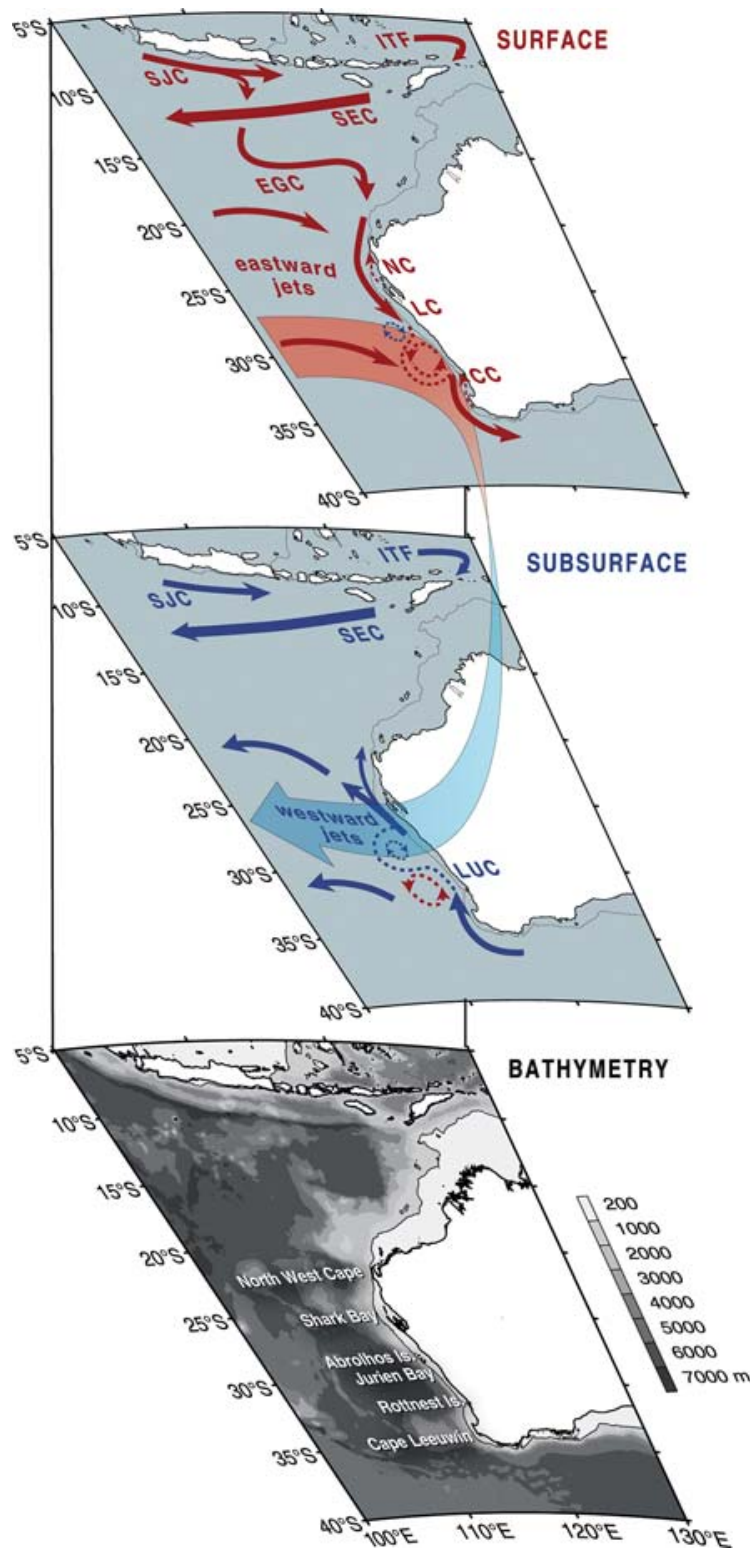

Fig. 6 Simplified schema of the surface currents off Western Australia emphasising the connection between the Leeuwin Current (LC) and Leeuwin Undercurrent (LUC) as a curved vertical arrow. Indicated is (1) the bathymetry and key coastal landmarks (bottom), (2) the subsurface (200-400 m) northward-flowing LUC, showing westward jets offshore, (3) the LC at the surface, fed by the eastward jets transporting Subtropical Water/South Indian Central Water into the LC and then the LUC. Abbreviations: ITF, Indonesian Throughflow; SJC, South Java Current; CC, Capes Current; and NC, Ningaloo Current. Figure adapted from Waite et al. (2007a), Fig. 1, and based on the circulation patterns described in Domingues et al. (2007), kindly supplied by Dr. Catia Domingues, CSIRO Marine and Atmospheric Research biomass of mesozooplankton, compared with those of $\mathrm{CC}$ eddies of the LC. This has been attributed partly to the origin of the water masses involved-e.g. entrainment of some nutrient-richer and more productive shelf/shelf break waters into the WC eddy during its formation as the Current runs south along the edge of the shelf (Strzelecki et al. 2007; Waite et al. 2007b). Whereas the CC eddy studied, in 2003 had a cap of warm Indian Ocean water, that seems to have limited upwelling between 1,000 and $500 \mathrm{~m}$ (Waite al 2007a) —and it is well-known that these offshore Indian Ocean waters are oligotrophic cf. slope and shelf waters (Tranter and Kerr 1969; Strzelecki et al. 2007). However, there was also a suggestion, from modelling results (Rennie et al. 2007) that, in general, the CC eddies may be sourced from the deeper LC Undercurrent.

This higher production found in WC eddies of this anomalous, eastern boundary current, is contrary to the findings of higher production in $\mathrm{CC}$ eddies (cf WC eddies) of western boundary currents such as the Gulf Stream off the USA. The mesoscale WC Leeuwin Current eddy was also found to have a healthier, although similar mesozooplankton community to that of the CC eddy, but with greater lipid storage (Waite et al. 2007b), which is an interesting fact in relation to the essential diet and known prey of late-stage phyllosomas (see McWilliam and Phillips 2007 and references therein).

\section{Panulirus japonicus}

The larval cycle of $P$. japonicus appears to be intimately related to the activities of the Kuroshio Current (Inoue and Sekiguchi 2001) and the distribution of final phyllosomas, as well as puerulus settlement, is probably influenced by the abovementioned changes in its pathway.

Yoshimura (2005) had data (4 specimens) of finalstage phyllosomas of $P$. japonicus metamorphosing to pueruli in relation to the Kuroshio Current off southern Japan. Because mid- and late-stage phyllosomas were found in the ocean south of the Kuroshio, whereas most final-stage larvae were caught within this current (Yoshimura et al. 1999, 2002), Yoshimura (2005) inferred that metamorphosis occurs offshore within the Kuroshio Current as discussed above. Yoshimura (2005) also added that their 
Fig. 7 Sampling areas for percentages of Panulirus cygnus phyllosomal stages in samples and total percentages of phyllosomas caught each night during June and July 1976.

Numbers of phyllosomas caught are shown above histogram; transect length by horizontal lines below. All phyllosomal data are from Phillips et al. (1979, Fig. 4)

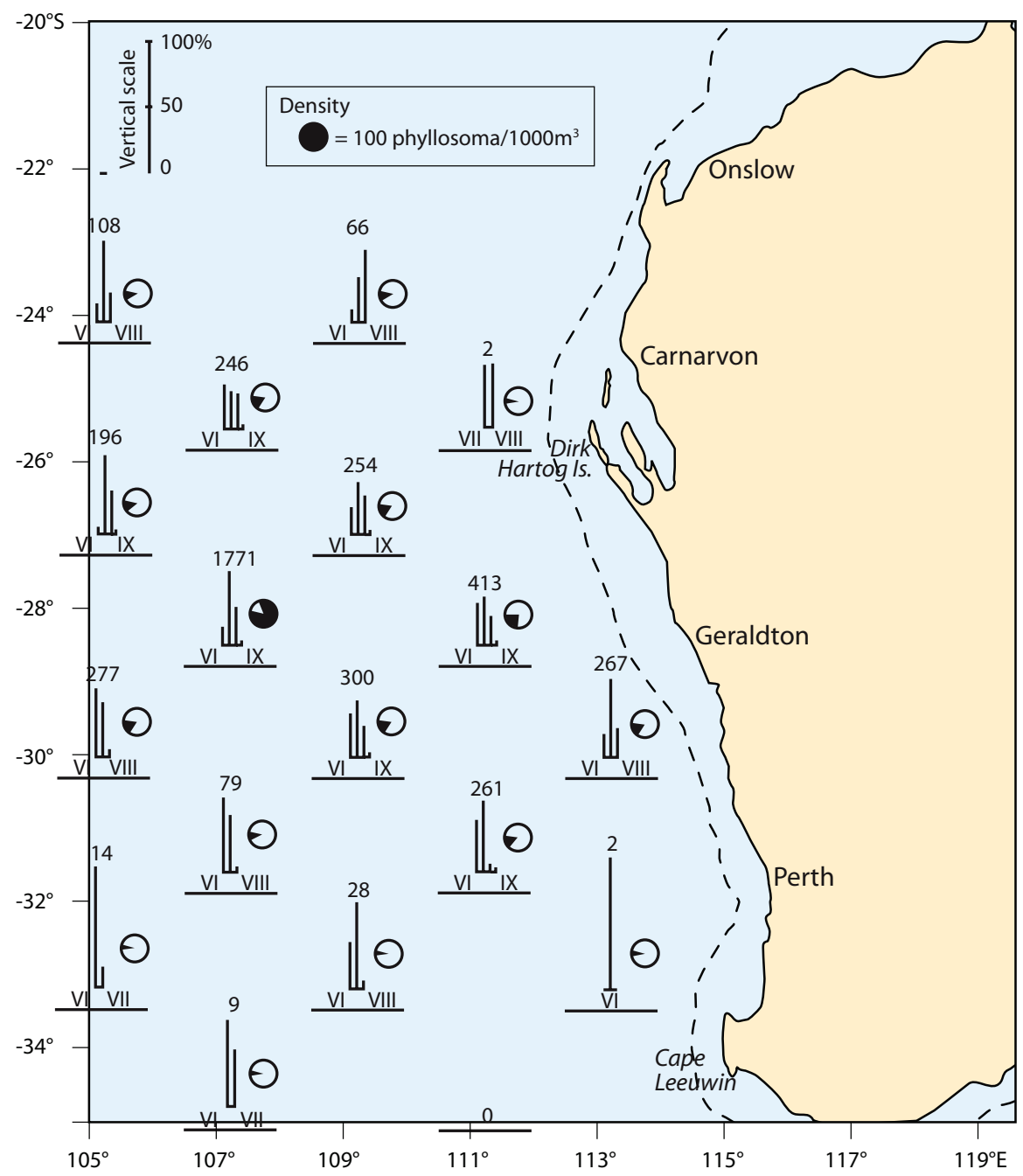

metamorphosis occurs, at night, at the surface or within $40 \mathrm{~m}$ of it, just after sunset or midnight, and between full moon and the last quarter.

\section{Panulirus ornatus}

Oceanic transport in the northwest Coral Sea is largely influenced by the influx of warm equatorial water flowing westward in the South Equatorial Current that enters between the Solomon Islands and Vanuatu (Church 1987), and bifurcates east of the Queensland Plateau (between about $16^{\circ} \mathrm{S}$ and $18^{\circ} \mathrm{S}$ ). The East Australian Current branch flows southward along the GBR to enter the Tasman Sea, while the northwardflowing branch forms a clockwise coastal current (the Hiri Current) along the shelf of Papua New Guinea and a partially closed gyre in the Gulf of Papua, with an exit into the Solomon Sea (Burrage 1993, Fig. 1).

Dennis (2005) stated that the majority of finalstage phyllosomas and pueruli of Panulirus spp. were caught at depths less than $25 \mathrm{~m}$ (presumably meaning ' $25 \mathrm{~m}$ from the surface in offshore waters') and most were caught near the surface (in night sampling presumably). Therefore he (Dennis) considered that the "larvae" [perhaps he really meant pueruli?] would be transported on-shore [sic] by surface currents produced by the prevailing South-East Trade Winds. This led to his conclusion that in P. ornatus, it is likely that most metamorphosis occurs near the shelf break and near the surface.

The question of the presence of numerous finalstage phyllosomas of $P$. ornatus at about $300 \mathrm{~km}$ 
offshore was raised by Dennis (2005). Many final (gilled) stages of $P$. ornatus occurred along the shelf break in the NW Coral Sea in May 1997, just prior to the time of peak settlement of this species. However, about 50 of the final-stage phyllosomas were collected about $300 \mathrm{~km}$ east of the GBR shelf break (see Fig. 5) in the South Equatorial Current which flows toward the Queensland coast. Five pueruli were also caught at this location, and 6 pueruli were caught slightly further offshore (where about 5 final-stage phyllosomas were also caught) about $600 \mathrm{~km}$ east of the GBR. The positions of these sampling sites are indicated by the arrows on Fig. 5. The image used is for 12 May 1997 , kindly made available by the CSIRO Division of Marine and Atmospheric Research.

The occurrence of these final-stage phyllosomas and pueruli of $P$. ornatus this far offshore is of interest, but needs to be put into perspective. It is not unusual to find late-stage, including final-stage, phyllosomas well offshore. Chittelborough and Thomas (1969) reported a total of 51 final stage phyllosomas of $P$. cygnus at varying distances offshore including seven which were about 1,130 km from the coast [sic] in May 1966.

Sampling off Western Australia in 1976 by Phillips et al. (1979) (see Table 2) yielded final-stage phyllosomas of $P$. cygnus at every station sampled. The data in Table 2 show final stage phyllosoma at all stations out to $1,360 \mathrm{~km}$ offshore. However, they may have occurred much farther offshore as the furthest offshore sampling site was at $99^{\circ} 70^{\prime} \mathrm{E}$. Similarly Booth (1994) found advanced phyllosomal stages of J. edwardsii $900 \mathrm{~km}$ offshore.

It is clear that reaching the final phyllosoma stage can occur in many distant offshore locations as shown by both $P$. cygnus and $P$. ornatus, but is no guarantee of metamorphosis to the puerulus stage. The situation with $P$. ornatus requires further comment because in addition to the final-stage phyllosomas of this species, some pueruli were caught at the same locations. This suggests that there may have been some sort of front occurring in this area, at this time.
It is interesting to note that the sampling data on P. ornatus reported by Dennis et al. (2001) came only from collections in May 1997, and Pitcher et al. (2005) remarked that this happened to be an "unusual year" because of the effects of Tropical Cyclone "Justin". It was also an El Nino year. The sampling data of J. edwardsii collected by Chiswell and Booth (1999), and used by Jeffs et al. (2001), are stated to have been collected in an "anomalous" kind of year (February 1998), when water temperatures were very warm. It is known that the above sampling data for both species was obtained in the strong El Nino year 1997-1998. However, the biological significance of either of these "unusual conditions" is unknown.

\section{Discussion}

The questions to be answered are:

Where does the majority of metamorphosis from final phyllosoma to puerulus occur?

A simple answer to this question is: beyond the shelf break (at the $200 \mathrm{~m}$ isobath) probably within ca. 100-150 km from it (depending on dimensions and distance offshore of the major local warm, ocean current(s) and in the more productive offshore areas where the final phyllosomal instars are most abundant. The shelf break is an area where fronts of large extent commonly occur and usually these result in high concentrations of plankton (see also Owen 1981). It was never suggested by McWilliam and Phillips (1997) that metamorphosis was associated with the shelf break per se. Although we have discussed only a few species in this review, the puerulus distribution of another shallow-water species, Jasus lalandii, in South Africa (Pollock 1986) is similar to that of J. edwardsii pueruli, being caught near to or on the continental shelf.

Table 2 Final stage phyllosoma larvae (Stage IX) of P. cygnus caught along $29^{\circ} 30^{\prime}$ S off Western Australia in September 1976

\begin{tabular}{lllllllll}
\hline Sampling location & $99^{\circ} 70^{\prime} \mathrm{E}$ & $101^{\circ} 85 \mathrm{E}$ & $103^{\circ} 80^{\prime} \mathrm{E}$ & $105^{\circ} 80^{\prime} \mathrm{E}$ & $107^{\circ} 80^{\prime} \mathrm{E}$ & $109^{\circ} 90^{\prime} \mathrm{E}$ & $111^{\circ} 80^{\prime} \mathrm{E}$ & $\begin{array}{l}\text { Width of } \\
\text { shelf }\end{array}$ \\
\hline Distance from shelf break & & & & & & & &
\end{tabular}


The above generalisation is drawn from quantitative, or semi-quantitative, sampling of final phyllosomas and/ or pueruli of four shallow-water species: P. cygnus (Phillips and Pearce 1997), P. japonicus (Yoshimura et al. 1999), P. ornatus (Dennis et al. 2001) and J. edwardsii (Chiswell and Booth 1999; Jeffs et al. 2001). The larval transport pathways of all four species are associated with a warm current-several in the case of the tropical species, P. ornatus in the Coral Sea. The latter also has a much shorter pelagic larval phase (4-7 months) than the subtropical and temperate-water species (P. cygnus and J. edwardsii, respectively), as does also the tropical species, $P$. argus, ca. 5-7 months in culture (Goldstein et al. 2006, 2008). The case for the main location of metamorphosis in P. argus in the Florida Keys region is inconclusive because of the complexities in defining 'offshore', plus the small number of samples made beyond the reef complex (Yeung 2005). However, sampling in other Caribbean waters (e.g. Baisre 1976; Alfonso et al. 1991) has indicated that this species probably also metamorphoses offshore.

These currents, which bring warmer tropical or subtropical waters to cooler regions, generate more productive (and extensive) frontal zones, eddies, and often nutrient enrichment by increased mixing with shelf waters or other water masses such as countercurrents. Compared with the oligotrophic waters further out to sea, and the usual patchiness of zooplankton, bioenergetic stores necessary for phyllosomal development and metamorphosis (see also McWilliam and Phillips 2007) can be readily accumulated by late-stage larvae feeding in the relatively more eutrophic waters nearer to the shelf. Slightly raised temperatures in the currents there will also result in shorter intermoult periods, ergo faster development (McWilliam and Phillips 1997).

For $P$. cygnus, the highest densities of final-stage larvae, and by inference, their metamorphosis, seem mainly to occur over the slope, within or near the warm Leeuwin Current which flows close to the shelf break. Thus the main region of their metamorphosis seems to be associated with more productive fronts near the borders of the Leeuwin Current (Phillips and Pearce 1997; Griffin et al. 2001), its offshoots and the periphery of the mesoscale Warm Core eddies which it often forms. Eddies may also be influential not only in aggregation of zooplankton (including the late phyllosomal stages and their suitable prey) near their border (see Owen 1981), but perhaps also, larval retention (Caputi et al. 2001, Fig. 2; Sponaugle et al. 2002). It is likely that this pattern of metamorphosis, mainly occurring within richer feeding areas closer to (but not on) the shelf, will pertain to other species of shallow-water palinurids. This seems to be apparent even from the distribution of newly metamorphosed pueruli of J. edwardsii (Jeffs et al. 2001, Fig. 1c, d, and is also indicated by Booth and Chiswell (2005).

All planktotrophic decapod larvae require exogenous food sources to attain metamorphic competency (Anger 2001). Therefore we think that, for all shallow-water palinurid species, including $P$. ornatus and $P$. argus, whose larval transport pathways are effected by multi-current systems (Dennis et al. 2001; Yeung et al. 2001), metamorphosis will occur mainly in, or adjoining, regions where there are sustained and richer food resources for instars of the penultimate and final stage phyllosomas at critical periods of their moulting cycles (McWilliam and Phillips 1997). This nutritional effect has been found experimentally for other decapod larvae (see Anger 2001, Chap. 4), and has been discussed more fully in our recent review (McWilliam and Phillips 2007). But we also think metamorphosis of these phyllosomas will only occur in those richer areas where water depths are greater than the normal daytime depth-distribution of the late larval stages of each species, for the phyllosoma form is not adapted for encounters with the natural substratum-hence this is another role for the transitional puerulus stage.

In the case of $P$. cygnus, we would also suggest that where metamorphosis seems mainly to occur is not entirely random, but rather due to selection pressures operating on all phases of development in this species: the behaviour of spawning females of $P$. cygnus, the larval cycle, and larval behaviour effective in larval transport, are geared to the seasonal (biannual) variation in strength of the Leeuwin Current (George 1997, 2006). Nanoplankton analyses have shown that a strong Proto-Leeuwin Current flowed down the Western Australian coast several times during the Eocene and middle to late Oligocene (Shafik 1990).

Nevertheless, it is unrealistic to suppose that more than a small proportion of any individual brood of a shallow-water palinurid species will recruit to its natal population. Why else have they evolved with such large numbers of eggs per brood? Having a 
lengthy, pelagic, larval phase is like entering a lottery-the more units invested, the greater the chance of a win. The chance of larval attrition, by advection too far out to sea, (especially if developing in an eddy) loss downstream if within the boundary Current), death by starvation or predation, or other factors, must be much greater than that of successful metamorphosis-and not every resulting puerulus may reach settlement. (see Yoshimura 2005).

\section{Where else does metamorphosis from final phyllosomal stage to puerulus occur, and how often?}

It is obvious that some metamorphosis occurs on some occasions far out to sea and as pointed out by Jeffs (2005) metamorphosis is not "restricted to the shelf break [region]".

Booth and Chiswell (2005) provided a plausible explanation for the occasional 'hard evidence' of metamorphosis of $J$. edwardsii occurring several hundreds of kilometres beyond the shelf break. They suggested that "every now and then some (late-stage phyllosomas) are transported into more productive waters. Here, where prey abundance is higher, the phyllosomas can stock up on food to reach some critical energy reserve level, and hence metamorphose". However, they concluded that metamorphosis "will usually occur near the shore [sic], in the region of the shelf break".

Jeffs et al. (2001), talking of J. edwardsii, stated a similar opinion when they said that there was a suggestion that metamorphosis could be associated with the inshore margins of oceanic eddies which are a dominant oceanographic feature of this region. We think Jeffs et al., had the right idea. For J. edwardsii it may be the inshore margins of the oceanic eddies. In the case of P. cygnus it is the inshore edge of the Leeuwin Current running down the edge of the shelf that is the most productive in biomass, and it is in this area that most pueruli are produced. However, any oceanic current or eddy could produce similar areas of high zooplankton biomass at their borders (i.e. frontal regions, where there is confluence of two different water masses) and if final phyllosomas in a suitable state of development are present, a number may metamorphose to pueruli. Not only the seaward edge of the Current, but also the periphery of the mesoscale, anticyclonic eddies produced frequently by the Leeuwin Current, provides frontal regions further offshore, and this may account for some pueruli being found so far offshore.

What is the likely fate of the pueruli found long distances offshore, hence what is their relevance to the recruitment process?

Jeffs et al. (1999, 2001) and Phillips et al. (2006) have all dealt with energy stores in the puerulus stage and discussed the ability of pueruli to swim to settlement sites and successfully moult into the first juvenile stage of either J. edwardsii or P. cygnus. Jeffs et al. (2001) estimated a maximum distance of $200 \mathrm{~km}$ for J. edwardsii, but Booth and Chiswell (2005) suggested that it was probably more like $100 \mathrm{~km}$.

It is hard to believe that pueruli such as the single specimen of a puerulus reported by Chittelborough and Thomas (1969) at somewhere between 359 and $519 \mathrm{~km}$ offshore, can successfully reach the shelf. The distances offshore from which the four species can successfully recruit are unknown, but presumably vary with species and the time of year, because of differences in the ocean circulation and water temperatures in a particular region. However, it is likely that few of the offshore pueruli survive and settle.

A study of pueruli of P. cygnus by Limbourn et al. (2008) showed that in addition to the energy reserves that are necessary to reach a settlement site near the shore, reserves are needed to sustain the animal until it has moulted to the juvenile stage and located adequate food to continue its growth and development. This further suggests that few of the animals that become pueruli well offshore will survive to adulthood.

\section{Conclusions}

Despite our attempts to define a number of terms at the beginning of this review, we have still found that the definitions of some of them are open to question. For example, what is "coastal", a term used by some authors? There are "coastal" currents such as the Leeuwin Current which, through its meanders, westward- propagating WC eddies, and jets, can influence the processes such as lobster recruitment by 
advecting final-stage phyllosomas out to at least $760 \mathrm{~km}$ beyond the shelf break (see Fig. 7) and perhaps a lot further offshore.

McWilliam and Phillips (1997) concluded that the main region of occurrence of metamorphosis in $P$. cygnus, is over the slope near the continental shelf break. However, while this was the picture to emerge from the sampling programs which were undertaken on several occasions, the situation may well vary with the scale of the ocean climate. Booth and Chiswell (2005) also considered changed climatic variations in February 1998 "a particularly warm February", with higher than average sea temperatures, could have accounted for some pueruli being swept up to $330 \mathrm{~km}$ from shore [sic], whereas most were caught within and about $50 \mathrm{~km}$ seaward of the shelf break (Chiswell and Booth 1999; Jeffs et al. 2001).

Bradford et al. (2005) summarised the vertical distribution of the phyllosomas of a number of spiny lobster species including P. cygnus, P. argus, and J. edwardsii discussed in this paper. Each species had different vertical behaviour patterns and it seems likely the pueruli of these species would also exhibit different diurnal vertical migration behaviour adding to the complexity of the transport processes and contributing to the difficulty of understanding them.

There is a lot of discussion about the retention of phyllosomas in eddies, but we doubt that this situation is always as beneficial to recruitment to natal populations as supposed-unless the eddy is a semi-permanent feature of the region, like the Wairarapa Eddy of New Zealand (Chiswell and Booth 1999). Consider the dynamics of a bunch of say sub-final and final-stage phyllosomas located near the rim of an eddy, e.g. the Wairarapa, or a Leeuwin Current one, and slowly circulating with the eddy (i.e. if their daytime vertical distribution is such that they still remain within it). From all the studies on the warm-core, mesoscale eddies of the East Australian Current, it seems that zooplankton abundance is poorer in the middle than at the edges, and richest just outside the rim of eddies. However, in their study of the pair of LC eddies, Strzelecki et al. (2007) found that the mesozooplankton was more abundant and had higher biomass in the WC eddy than in the CC eddy. Moreover, within each of these eddies, biomass at the perimeter and at the centre were not significantly different.
So the pueruli metamorphosing from phyllosomas feeding at the WC eddy perimeter have a swimming advantage, for if they happen to metamorphose where and when their part of the eddy rim is nearer or nearest to the shelf, then the chances of successful settlement are better than if they had metamorphosed on the seaward rim some $150-200 \mathrm{~km}$ or greater in the opposite direction. The same applies if metamorphosis had occurred on the shoreward rather than seaward edge of the particular current. We think this has some bearing on why more pueruli are found near the shelf, than well offshore. If the final phyllosomal instars do not reach metamorphic competency when that "gate" is open, then they are likely to be lost out to sea, or downstream, if still in an eddy or current.

What is most needed now, to advance the topic of this review, is a new multidisciplinary approach with new collections of late-stage phyllosomas, other zooplankton, biomass data and concurrent oceanographic data. This would probably need to be conducted by two vessels and obtaining funding is likely to be a major obstacle to such a project.

Acknowledgments The authors acknowledge the assistance of Sandy Clarke from the Department of Fisheries in Western Australia in preparing the illustrations. Also a special thanks to Dr Yoshimura Taku (Seikai National Fisheries Research Institute) and Dr Steve Chiswell (NIWA, New Zealand) for supplying the figures used to illustrate the areas off Japan and New Zealand, respectively. We also thank Louise Bell for preparing the tif file of Fig. 6 which Dr Catia Domingues (CSIRO Marine and Atmospheric Research, Tasmania) kindly made available. The comments by Dr Roy Melville-Smith (Department of Fisheries, Western Australia) and Dr Steve Chiswell on an earlier draft of this manuscript are also appreciated. The satellite image used in Fig. 5 was kindly provided by the CSIRO Division of Marine and Atmospheric Research.

Open Access This article is distributed under the terms of the Creative Commons Attribution Noncommercial License which permits any noncommercial use, distribution, and reproduction in any medium, provided the original author(s) and source are credited.

\section{References}

Abrunhosa FA, Kittaka J (1997) The morphological development of juvenile western rock lobster, Panulirus cygnus George, 1952 (Decapoda, Palinuridae) reared in the laboratory. Bull Mar Sci 61:81-96

Alfonso I, Frias P, Baisre J (1991) Distribución y abundancia de larvas de la langosta Panulirus argus en aguas alrededor de Cuba. Rev Inv Mar 2(1-3):3-19 
Anger K (2001) The biology of decapod crustacean larvae. A.A. Balkema Publishers, Lisse Abingdon

Baisre JA (1976) Distribucion de las larvas de Panulirus argus y Scyllarus americanus (Crustacea, Decapoda) en aguas alrededor de Cuba. Rev Inv Nac Pesca Cuba 2:277-297

Baisre JA, Alfonso I (1994) Late stage larvae of Panulirus guttatus (Latreille, 1804) (Decapoda, Palinuridae) with notes on the identification of phyllosomata of Panulirus in the Caribbean Sea. Crustaceana 66:32-43. doi:10.1163/ $156854094 X 00134$

Baisre JA, Ruiz de Quevedo ME (1982) Two phyllosome larvae of Panulirus laevicauda (Latreille, 1817) (Decapoda, Palinuridae) from the Caribbean Sea with a discussion about larval groups within the genus. Crustaceana 43:147-153. doi:10.1163/156854082X00470

Booth J (1994) Jasus edwardsii larval recruitment off the east coast of New Zealand. Crustaceana 66(3):295-317. doi: $10.1163 / 156854094$ X00044

Booth J, Chiswell S (2005) Food is the factor. Lobster Newsl 18(2):15-18. http://www.odu.edu/ mbutler/newsletter/ index.html

Booth JD, Phillips BF (1994) Early life history of spiny lobster. Crustaceana 66:271-294. doi:10.1163/156854094X00035

Booth JD, Stewart RA (1991) Distribution of phyllosoma larvae of the red rock lobster Jasus edwarsii off the east coast of New Zealand in relation to the oceanography. In: Hancock DA (ed) Larval biology, Bureau of Rural Resources Proc No. 15, Aust Soc Fish Biology, Workshop, Hobart, 20 August 1991

Bradford RW, Bruce BD, Chiswell SM (2005) Vertical distribution and diurnal migration patterns of Jasus edwardsii phyllosomas off the east coast of the North Island, New Zealand. N Z J Mar Freshw Res 39:593-604

Braine SJ, Rimmer DW, Phillips BF (1979) An illustrated key and notes on the phyllosoma stages of the western rock lobster Panulirus cygnus George. CSIRO Division of Fisheries and Oceanography, Report No. 102

Briones-Fourzan P, Candela J, Lozano-Alvarez E (2008) Postlarval settlement of the spiny lobster Panulirus argus along the Caribbean coast of Mexico: patterns, influence of physical factors, and possible sources of origin. Limnol Oceanogr 53:970-985

Briones-Fourzán P, Lozano-Álvarez E, Colinas-Sánchez F, Negrete-Soto F (1988) Distribución de larvas filosomas de la familia Palinuridae (langostas espinosas) en al Caribe mexicano y plataforma de Yucatán. In: Biología y dinámica poblacional de las langostas del Caribe mexicano. Informe final, Proyecto PCECBNA-021927, CONACYT/ Instituto de Ciencias del Mar y Limnología, UNAM, pp 46-70

Bruce B, Bradford R, Griffin D (2000) A synthesis of existing data on larval rock lobster distribution in southern Australia. Final Report, Project No. 96/107, Fisheries Research and Development Corporation, Hobart, CSIRO Marine Research

Burrage DM (1993) Coral Sea currents. Corella 17:135-145

Caputi N, Chubb C, Pearce A (2001) Environmental effects on recruitment of the western rock lobster, Panulirus cygnus. Mar Freshw Res 52:1167-1174. doi:10.1071/MF01180

Chiswell SM, Booth JD (1999) Rock lobster Jasus edwardsii larval retention by the Wairarapa Eddy off New Zealand.
Mar Ecol Prog Ser 183:227-240. doi:10.3354/meps 183227

Chiswell SM, Booth JD (2005) Distribution of mid- and latestage Jasus edwardsii phyllosomas: implications for larval recruitment processes. N Z J Mar Freshw Res 39: $1157-1170$

Chittelborough RG, Thomas LR (1969) Larval ecology of the Western Australian marine crayfish, with notes upon other panulirid larvae from the eastern Indian Ocean. Aust J Mar Freshw Res 20(3):199-223. doi:10.1071/MF9690199

Chow S, Suzuki N, Imai H et al (2006a) Molecular species identifications of spiny lobster phyllosoma larvae of the genus Panulirus from the Northwestern Pacific. Mar Biotechnol 8:260-267. doi:10.1007/s10126-005-5151-9

Chow S, Yamada H, Suzuki N (2006b) Identification of mid to final stage lobster phyllosoma larvae of the genus Рапиlirus White 1847, collected in Ryuku Archipelago. Crustaceana 79(6):745-764. doi:10.1163/15685400677 8026771

Church JA (1987) East Australian Current adjacent to the Great Barrier Reef. Aust J Mar Freshw Res 38:671-683. doi: 10.1071/MF9870671

Cresswell GR, Golding TJ (1980) Observations of a southflowing current in the southeastern Indian Ocean. Deep-Sea Res 27A:449-466. doi:10.1016/0198-0149(80)90055-2

Dennis DM (2005) Coral Sea Panulirus ornatus. Lobster Newsl 18(2):4-15. http://www.odu.edu/ mbutler/news letter/index.html

Dennis DM, Pitcher CR, Skewes TD (2001) Distribution and transport pathways of Panulirus ornatus and Panulirus spp. larvae in the Coral Sea, Australia. Mar Freshw Res 52:1175-1185. doi:10.1071/MF01186

Domingues CM, Maltrud ME, Wijeffels SE et al (2007) Simulated Langrangian pathways between the Leeuwin current system and the upper-ocean circulation of the southeast Indian Ocean. Deep Sea Res Part II Top Stud Oceanogr 54:797-817. doi:10.1016/j.dsr2.2006.10.003

Felder DL, Martin JW, Goy JW (1985) Patterns in early postlarval development of decapods. In: Wenner AM (ed) Larval growth. A.A. Balkema, Rotterdam

George RW (1997) Tectonic plate movements and the evolution of Jasus and Panulirus spiny lobsters. Mar Freshw Res 48:1121-1130. doi:10.1071/MF97202

George RW (2006) Tethys Sea fragmentation and speciation of Panulirus spiny lobsters. Crustaceana 78:1281-1309. doi: $10.1163 / 156854005776759780$

Goldstein J, Matsuda H, Butler M (2006) Success! Caribbean spiny lobster, Panulirus argus is cultured from egg to juvenile for the first time. Lobster Newsl 19(1):3-4. http://www.odu.edu/ mbutler/newsletter/index.html

Goldstein JS, Matsuda H, Takenouchi T (2008) A description of the complete development of larval Caribbean spiny lobster, Panulirus argus (Latreille, 1804) in culture. J Crust Biol 28(2):306-327. doi:10.1651/0278-0372(2008) 028[0306:TCDOLC]2.0.CO;2

Gore RH (1985) Molting and growth in decapod larvae. In: Wenner AM (ed) Larval growth. A.A. Balkema, Rotterdam

Griffin DA, Wilkin JL, Chubb CF et al (2001) Mesoscale oceanographic data analysis and data assimilative modelling with application to western Australian fisheries. 
FRDC Projecst No. 1997/1.39, CSIRO Marine Research, August 2001

Inoue N, Sekiguchi H (2001) Distribution of late-stage phyllosoma larvae of Panulirus japonicus in the Kuroshio Subgyre. Mar Freshw Res 52:1201-1209. doi:10.1071/ MF01184

Jeffs AG (2005) Metamorphosis in spiny lobsters. Lobster Newsl 18(2):10-12. http://www.odu.edu/ mbutler/news letter/index.html

Jeffs AG, Holland RC (2000) Swimming behaviour of the puerulus of the spiny lobster Jasus edwardsii (Hutton, 1875) (Decapoda, Palinuridae). Crustaceana 73:847-856. doi:10.1163/156854000504859

Jeffs AG, Willmott ME, Wells RMG (1999) The use of energy stores in the puerulus of the spiny lobster Jasus edwardsii across the continental shelf of New Zealand. Comp Biochem Physiol A 123:351-357. doi:10.1016/S1095-6433 (99)00073-2

Jeffs AG, Chiswell SM, Booth JD (2001) Distribution and condition of pueruli of the spiny lobster Jasus edwardsii offshore from north-east New Zealand. Mar Freshw Res 52:1211-1216. doi:10.1071/MF01182

Jeffs AG, Montgomery J, Tindle CT (2005) How do spiny lobster post-larvae find the coast? N Z J Mar Freshw Res 39:605-617

Lee TN, Clarke ME, Williams E (1994) Evolution of the Totugas Gyre and it influence on recruitment in the Florida Keys. Bull Mar Sci 54:621-646

Limbourn AJ, Babcock RC, Johnston DJ (2008) Post-settlement energy reserves in Panulirus cygnus: experimental effects of starvation on survival and nutritional condition. Mar Biol (Berl) 153:445-456. doi:10.1007/s00227-007-0825-7

Lyons WG (1981) Possible sources of Florida's spiny lobster population. Proc Gulf Caribb Fish Inst 33:253-266

Manzanilla-Dominguez H, Gasca R (2004) Distribution and abundance of phyllosoma larvae (Decapoda, Palinuridae) in the southern Gulf of Mexico and the western Caribbean Sea. Crustaceana 77:75-93. doi:10.1163/15685400432 3037900

McWilliam PS, Phillips BF (1997) Metamorphosis of the final phyllosoma and secondary lecithotrophy in the puerulus of Panulirus cygnus George: a review. Mar Freshw Res 48:783-790. doi:10.1071/MF97159

McWilliam PS, Phillips BF (2007) Spiny lobster development: mechanism(s) inducing metamorphosis to the puerulus stage: a review. Rev Fish Biol Fish 17:615-632. doi: 10.1007/s11160-007-9067-5

Owen RW (1981) Fronts and eddies in the sea: mechanisms, interactions and biological effects. In: Longhurst AR (ed) Analysis of marine ecosystems. Academic Press, London

Pearce AF, Phillips BF, Crossland CJ (1992) Larval distributions across the Leeuwin Current: report on RV Franklin Cruise Fr8/87 in August/September 1987. CSIRO Marine Laboratories Report No. 217

Phillips BF (1981) The circulation of the southeastern Indian Ocean and the planktonic life of the western rock lobster. Oceanogr Mar Biol Ann Rev 19:11-39

Phillips BF, Pearce AF (1997) Spiny lobster recruitment off Western Australia. Bull Mar Sci 61:21-41

Phillips BF, Rimmer DW, Reid DD (1978) Ecological investigations of the late-stage phyllosoma and puerulus larvae of the western rock lobster Panulirus longipes cygnus. Mar Biol (Berl) 45:347-357. doi:10.1007/BF00391821

Phillips BF, Brown PA, Rimmer DW et al (1979) Distribution and dispersal of the phyllosoma larvae of the western rock lobster, Panulirus cygnus, in the southeastern Indian Ocean. Aust J Mar Freshw Res 30:773-783. doi:10.1071/ MF9790773

Phillips BF, Jeffs AG, Melville-Smith R et al (2006) Changes in lipid and fatty acid composition of late larval and puerulus stages of the spiny lobster (Panulirus cygnus) across the continental shelf of Western Australia. Comp Biochem Physiol Part B 143:219-228 (see my note 2). doi:10.1016/j.cbpb.2005.11.009

Pitcher CR, Turnbull C, Atfield J et al (2005) Biology, larval transport modelling and commercial logbook data analysis to support management of the NE Queensland rock lobster Panulirus ornatus fishery. CSIRO, Queensland Government Department of Primary Industries and Fisheries, Australian Government Fisheries Research and Development Corporation. Project No. 2002/008, September 2005

Pollock DE (1986) Review of the fishery for and biology of rock lobster Jasus lalandii with notes on larval recruitment. Can J Fish Aquat Sci 43:2107-2117

Rennie SJ, Pattiaratchi CB, Ivey GN (2007) Eddy formation through the interaction between the Leeuwin Current, Leeuwin Undercurrent and topography. Deep Sea Res Part II Top Stud Oceanogr 54:818-836. doi:10.1016/j.dsr2. 2007.02.005

Richards WJ, Potthoff T (1980) Distribution and seasonal occurrence of larval pelagic stages of spiny lobsters (Palinuridae, Panulirus) in the western tropical Atlantic. Proc Gulf Caribb Fish Inst 33:244-252

Ritz DA (1972) Factors affecting the distribution of rock lobster larvae (Panulirus longipes cygnus) with reference to variability of plankton-net catches. Mar Biol (Berl) 13:309-317. doi:10.1007/BF00348078

Shafik S (1990) The Maastrichian and early tertiary record of the great Australian basin and its onshore equivalents on the Australian southern margin. J Aust Geol Geophys 11:473-497

Shirai SM, Yoshimura T, Konishi K et al (2006) Identification of phyllosoma larvae: a molecular approach for Japanese Panulirus lobsters (Crustacea: Decapoda: Palinuridae) using mitochondrial rDNA region. Species Divers 11:307-325

Sims HW, Ingle RM (1966) Caribbean recruitment of Florida's spiny lobster populations. Q J Fla Acad Sci 29:207-243

Sponaugle S, Cowen RK, Shanks A (2002) Predicting selfrecruitment in marine populations: biophysical correlates. Bull Mar Sci 49:341-375

Strzelecki J, Koslow A, Waite A (2007) Comparison of mesozooplakton communities from a pair of warm- and coldcore eddies off the coast of Western Australia. Deep Sea Res Part II Top Stud Oceanogr 54:1103-1112. doi: 10.1016/j.dsr2.2007.02.004

Tomczak M, Godfrey JS (2005) Regional oceanography: an introduction, 2nd edn. Daya Publishing House, Delhi

Tranter DJ, Kerr JD (1969) Seasonal variation in the Indian Ocean along $110^{\circ}$ E. Aust J Mar Freshwat Res 20:77-814. doi:10.1071/MF9690077

Waite AM, Thomson PA, Pesant S et al (2007a) The Leeuwin Current and its eddies: an introductory overview. Deep Sea Res Part II Top Stud Oceanogr 54:89-796 
Waite AM, Muhling BA, Holl CM et al (2007b) Food web structure in two counter-rotating eddies baed on $\tilde{\mathrm{o}}^{15} \mathrm{~N}$ and $\tilde{\mathrm{o}}^{13} \mathrm{C}$ isotopic analyses. Deep Sea Res Part II Top Stud Oceanogr 54:1055-1107. doi:10.1016/j.dsr2.2006.12.010

Yeung C (2005) The Florida spiny lobster. Lobster Newsl 18(2):12-13. http://www.odu.edu/ mbutler/newsletter/index. html

Yeung C, Lee TN (2002) Larval transport and retention of the spiny lobster, Panulirus argus, in the coastal zone of the Florida Keys, USA. Fish Oceanogr 11(5):286-309. doi: 10.1046/j.1365-2419.2002.00209.x

Yeung C, McGowan MF (1991) Differences in inshore-offshore and vertical distribution of phyllosoma larvae of Panulirus, Scyllarus and Scyllarides in the Florida Keys in May-June, 1989. Bull Mar Sci 49:699-714

Yeung C, Jones DL, Criales MM et al (2001) Influence of coastal eddies and counter-currents on the influx of spiny lobster, Panulirus argus, postlarvae in Florida Bay. Mar Freshw Res 52:217-232. doi:10.1071/MF01110

Yoshimura T (2005) The final-stage phyllosoma metamorphoses to the puerulus while caught up in the flow of the Kuroshio? Lobster Newsl 18(2):18-21 http://www.odu. edu/ mbutler/newsletter/index.html

Yoshimura T, Yamakawa H, Kozasa E (1999) Distribution of final stage phyllosoma larvae and free-swimming pueruli of Panulirus japonicus around the Kuroshio Current off southern Kyusyu, Japan. Mar Biol (Berl) 33:293-306. doi: 10.1007/s002270050468

Yoshimura T, Morinaga K, Shirai S et al (2002) Palinurid phyllosoma larvae and their distribution in winter off the Pacific coast of Japan. Fish Sci 68(supp 1):194-197 